\title{
RANCANGAN PEMBELAJARAN
}

\section{SENI GRAFIS 2 (Serigraphy)}

\begin{tabular}{|c|} 
SILABUS \\
SATUAN ACARA PERKULIAHAN (SAP) \\
BUKU AJAR
\end{tabular}

Dosen:

Drs. Ariusmedi, M. Sn.

Drs. Irwan, M. Sn.

PROGRAM STUDI : PENDIDIKAN SENI RUPA JURUSAN SENI RUPA - FAKULTAS BAHASA DAN SENI

2012 
Buku Ajar

Bahan Kajian

SKS

: Seni Grafis 2 (serigraphy)

Program Studi

: 3 (tiga)

Pertemuan Ke

: Pendidikan Seni Rupa

Dosen

$: 1-2$

: Drs. Ariusmedi, M.Sn.

Drs. Irwan, M.Sn.

\section{Learning Outcomes (Capaian Pembelajaran) terkait KKNI}

Ruang Lingkup Seni Grafis serta bagian-bagiannya:

a. Sejarah singkat, perkembangan, serta potensi Serigraphy sebagai salah satu teknik dalam karya seni murni.

b. Memahami beberapa cara/metode dalam teknik Serigraphy, yang diarahkan pada aspek kreativitas kebebasan dalam berkarya seni

Soft skills/Karakter: Memahami tentang perkembangan Seni Grafis khususnya Serigraphy sebagai karya seni murni.

\section{Bagian 1}

\section{Pengetahuan/pemahaman}

\section{Materi :}

a. Ruang lingkup serta perkembangan Seni Grafis dalam karya seni rupa murni.

b. Serigraphy sebagai alternatif pilihan dalam berkesenian

c. Pengetahuan tentang cetak mencetak dua dimensi

\section{Pengantar}

Dalam bagian pertama ini dipaparkan teori serta pengetahuan tentang ruang lingkup serta perkembangan seni grafis khususnya teknik serigraphy. Waktu yang dialokasikan pada bagian ini adalah 2 (dua) kali tatap muka. Dengan alokasi yang sudah ditetapkan tersebut diharapkan mahasiswa dapat memahami diantaranya; tentang ruang lingkup dan perkembangan seni grafis, serigraphy sebagai bagian dari seni grafis serta pengetahuan tentang metode-metode yang dapat diterapkan dalam praktik studio. 


\section{Penyajian/Uraian Materi}

Sekilas tentang Cetak Sablon

Cetak sablon atau cetak saring telah lama dikenal oleh bangsa Jepang sejak tahun 1664. Ketika itu, Yuzensai Miyasaki dan Zisukeo Mirose mengembangkannya dengan menyablon kain kimono beraneka motif. Penyablonan kimono ini dilatar-belakangi oleh kebijakan Kaisar Jepang yang melarang penggunaan kimono bermotif tulis tangan. Pasalnya, Kaisar sangat prihatin dengan tingginya harga kimono motif tulis tangan yang beredar di pasaran. Dengan kebijakan tersebut, harga kimono dapat ditekan, dan kimono motif sablon mulai banyak digunakan masyarakat Jepang. Sejak itu, teknik cetak sablon terus berkembang dan merambah ke berbagai negara. Sablon pada saat itu belum memakai kain gasa atau screen, mereka masih menggunakan teknik pencapan atau menggunakan model cetakan atau mal. Pada tahun 1907, seorang pria berkebangsaan Inggris, Samuel Simon, mengembangkan teknik sablon menggunakan Chiffon sebagai pola (form) untuk mencetak. Chiffon merupakan bahan rajut yang terbuat dari benang sutera halus. Bahan rajut inilah yang merupakan cikal bakal kain gasa untuk menyablon. Prinsip kerja dengan cara ini adalah, tinta yang digunakan untuk mencetak dialirkan melalui kain gasa atau kain saring. Gambar yang tercetak akan mengikuti pola gambar yang ada pada kain gasa. Itu sebabnya teknik ini dikenal dengan sebutan silk screen printing, yang berarti mencetak menggunakan kain saring sutera.

Kata sablon berasal dari bahasa Belanda yakni schablon. Dalam kamus besar bahasa Indonesia, kata sablon didefinisikan sebagai pola berdesain yang dapat dilukis berdasarkan contoh.

\section{Pengertian Cetak Saring}

Cetak saring adalah teknik cetak yang acuan cetaknya tidak tinggi, tidak datar, dan juga tidak dalam, tetapi pencetakannya dikerjakan dengan menggunakan selembar layar atau kain penyaring (screen) yang dikenal dengan nama gasa sutra halus atau monyl (Sutarmo, 1983 : 5). Karena acuan cetaknya 
terbuat dari gasa sutra halus seperti saringan, maka proses cetak disebut cetak saring. Proses cetak ini sangat cocok untuk pekerjaan yang oplagnya tidak terlalu banyak. Kelebihan dari proses cetak ini yakni dapat diterapkan pada setiap macam bentuk dan sifat benda, baik yang berbentuk datar maupun yang berbentuk lengkungan. Demikian pula dengan jenis dan karakter dari benda yang akan dicetak, baik pada benda yang meresap tinta maupun tidak meresap, misalnya, pada kaca, plastik, logam, kertas, kain, dan sebagainya.

\section{Ruang lingkup Seni Grafis}

Secara sederhana, seni grafis adalah bentuk ungkapan seni rupa dua dimensi yang memanfaatkan metode cetak-mencetak. Karenanya, karya grafis memungkinkan berjumlah lebih dari satu, berbeda dengan karya lukis yang tunggal atau hanya satu. Dengan demikian suatu karya grafis yang sama dapat dinikmati atau dimiliki oleh banyak peminat. Proses cetak dalam seni grafis cenderung terbatas pada proses yang normal, suatu proses yang langsung melibatkan keterampilan tangan sang seniman.

Meskipun keduanya menggunakan proses cetak, karya seni grafis dibedakan dari karya reproduksi. Karya reproduksi lahir dari kebutuhan untuk memperbanyak suatu karya tunggal (misalnya lukisan, foto), biasanya dengan teknik cetak mekanis-fotografis, dan cenderung untuk kebutuhan massa. Sedangkan karya seni grafis bertitik tolak dari kebutuhan seni dari senimannya.

Karena faktor pekerjaan yang seringkali membutuhkan waktu yang lama dan peralatan cetak yang sederhana, maka jumlah hasil cetakan suatu karya seni grafis biasanya dalam jumlah yang terbatas dan disebut sebagai karya "cetak murni" (original print). Untuk mempertegas orisinalitas karya seni grafis, senimannya selalu membubuhkan tanda tangan, tahun pembuatan, judul karya, dan tanda nomor urut cetak serta jumlah cetakan pada bagian bawah karyanya dengan menggunakan pensil, misalnya 10/25 berarti cetakan ke 10 dari 25 jumlah cetakan.

Pemberian warna bagi pembuat karya grafis (seniman grafis) dapat dilakukan dengan banyak cara. Ada yang menerapkan dengan cara menggunakan bahan 'klise' yang terpisah atau teknik pewarnaan multi-klise, dan ada juga dengan 
menggunakan pendekatan 'reduksionis'. Dalam teknik pewarnaan multi-klise, terdapat sejumlah 'klise', yang masing-masingnya menghasilkan warna yang berbeda. Klise yang terpisah dan menghasilkan warna yang berbeda tersebut kemudian diterapkan pada tahapan tertentu untuk menghasilkan karya secara keseluruhan. Rata-rata digunakan 3 sampai 4 klise untuk mendapatkan karya yang multi colour, bahkan adakalanya seorang seniman grafis menggunakan sampai dengan tujuh klise. Tiap penerapan warna akan berinteraksi dengan warna lain yang telah diterapkan pada bidang cetakan. Biasanya warna yang paling terang diterapkan lebih dahulu, selanjutnya ke warna yang lebih gelap.

Pada pendekatan 'reduksionis' untuk menghasilkan warna pertama biasanya dimulai dengan 'mencetak' dari 'klise' dalam keadaan kosong, sebelum melakukan proses cetak. Kemudian melanjutkan dengan unsur rupa lainnya, sesuai dengan konsep dan rancangan dalam berkarya. Hal ini berlanjut terus, sampai mendapatkan wujud karya serta pewarnaan yang diinginkan. Prinsipnya, pada proses ini bagian klise yang 'digarap' akan menampilkan warna yang telah tercetak sebelumnya. Demikian seterusnya, sehingga 'klise' yang digunakan mengalami pengurangan secara berangsur-angsur (proses terjadinya reduksi pada bahan klise).

Secara umum, proses seni grafis dapat diklasifikasikan menjadi empat teknik dasar, yaitu; cetak-tinggi (relief print), cetak-dalam (intaglio), cetak-datar (lithography) dan cetak saring (silk screen printing).

Dari beberapa teknik cetak grafis yang disebutkan di atas, cetak silk screen printing' merupakan teknik yang relatif baru di kalangan pekerja seni. Penggunaan teknik 'silk screen printing' pada awalnya lebih banyak dimanfaatkan sebagai medium pada konteks seni terapan yang lebih berorientasi kepada selera pasar (komersil). Seiring dengan perjalanan waktu dan tuntutan kreativitas dari pekerja seni, maka dicoba untuk memanfaatkan teknik 'silk screen printing' sebagai media dalam berkarya seni murni (fine art medium). Meskipun pada awalnya mengalami kemunduran sampai beberapa puluh tahun kemudian.

Adalah "Anthony Velonis" sebagai salah seorang pekerja seni berkebangsaan Amerika yang menghidupkan kembali, serta memberikan dorongan dari pada 
perkembangan 'silk screen printing' sebagai media dalam berkarya seni murni (fine art). Tokoh-tokoh lain yang ikut andil dalam membantu perkembangan teknik ini, diantaranya, adalah; Carol Zigrosser, Hyman Warsager, Guy Mac Coy, Harry Stornberg dan lain-lain.

Carol Zigrosser, yang menjabat sebagai curator dalam bidang 'print' di Philadelphia Museum of Art yang pertama-tama membuat perbedaan tegas antara silk screen printing sebagai media seni terapan/komersil terhadap silk screen printing sebagai media seni murni (fine art). Dalam konteks seni murni (fine art), ia memberikan istilah dengan sebutan 'serigrafi'. Serigrafi berasal dari penggalan kata 'seri' (latin) yang berarti sutra, dan kata 'graphein' (Yunani), yang berarti menulis atau menggambar. Sedangkan 'silk screen printing' berasal dari bahasa Inggris, bila diterjemahkan dari apa yang tertulis, dapat diartikan; 'mencetak dengan layar sutera'.

Istilah lain yang sering juga digunakan dalam media serigrafi ini adalah cetak saring. Sesuai dengan istilahnya, proses ini mengandalkan penyaringan dalam pencetakannya. Di sini yang berperan sebagai acuan cetak adalah alat saring yang terbuat dari sejenis kain sutera yang lebih dikenal dengan "monyl". Konsep sederhananya adalah, dimana bagian bergambar merupakan bagian terbuka pada saringan tersebut, dengan demikian bagian bergambar (terbuka) akan meloloskan tinta ke atas kertas yang akan dicetak. Potensi ungkapan rupa melalui media cetaksaring terletak pada kemampuannya untuk menerapkan banyak warna pada karya dan warna-warna itu bisa tampil utuh serta tetap cerah.

Serigrafi sebagai salah satu teknik dalam seni grafis

Dalam konteks seni terapan, sebutan cetak sablon lebih populer dan sudah dikenal masyarakat luas dewasa ini. Namun proses cetak dengan istilah-istilah; silk screen printing, serigrafi, maupun cetak saring, sudah merupakan bagian dari karya seni grafis dalam konteks seni murni. Selanjutnya, untuk menghindari kesalah-pahaman serta menyamakan persepsi bagi pembaca, istilah yang dipakai dalam buku ajar ini adalah 'serigrafi'. 
Metode atau cara dalam teknik 'serigrafi'

1. Metode pola potong

2. Metode fotografis/afdruk

3. Metode blok/colet

4. Metode kombinasi

Metode pola potong

Sebelum ditemukannya obat afdruk dan gasa screen, pelaksanaan proses cetak dua dimensi dilakukan dengan metode pola potong. Bahkan jauh sebelumnya proses cetak dilakukan dengan memanfaatkan lembaran kertas atau plastik yang dilobangi, menggunakan alat yang runcing atau tajam sebagai pola/motif gambar yang akan dicetak. Cara ini merupakan metoda tertua dan primitif, namun sampai sekarang masih dimanfaatkan untuk mengerjakan berbagai keperluan, misalnya; untuk pemberian merek-merek atau lambang-lambang pada suatu produk dalam bidang industri dan perusahaan tertentu. Metode pengerjaan seperti ini, hanya terbatas pada obyek gambar (motif) yang relatif besar dan hanya dengan jumlah cetakan yang tidak begitu banyak.

Pada prinsipnya, dengan metode pola potong ini, lembaran kertas atau plastik yang digunakan sebagai acuan cetak adalah memanfaatkan adanya posisi positif dan negatif pada permukaan 'klise'. Gambar cetak didapatkan dengan menyaputkan atau dengan menyemburkan 'pigmen' (pewarna) melalui celah-celah yang terbuka (posisi negatif) dari permukaan 'klise' tersebut. Proses cetak dari metode ini sebenarnya sangat sederhana, yaitu meloloskan pewarna (tinta cetak) ke atas bidang atau barang yang akan dicetak sesuai dengan pola gambar yang telah dipotong-potong sebelumnya. Setelah 'menyemburkan' secara merata bahan pewarna ke atas permukaan/bidang yang akan dicetak, selanjutnya 'acuan' cetakan diangkat, hasilnya adalah sebuah gambar/motif, sesuai dengan pola (bagian yang berlobang) dari 'acuan' cetakan tersebut. Proses ini dikerjakan secara berulangulang, sampai jumlah cetakan sudah dipenuhi, atau bila 'acuan' cetaknya tidak dapat digunakan lagi. 


\section{Contoh karya}
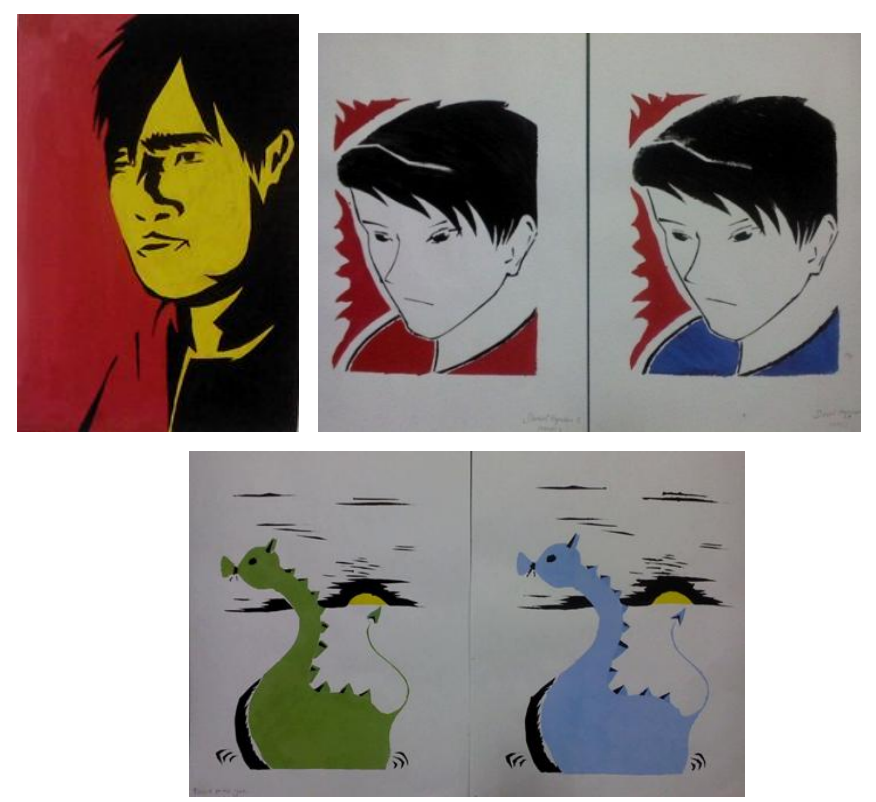

Alat dan bahan yang digunakan pada metode pola potong

- Kertas karton atau plastik transparan yang digunakan sebagai bidang klise.

- Kertas gambar, yang digunakan sebagai bidang/lembaran yang akan dicetak.

- Cat tembok, sebagai bahan dasar dalam pemberian warna setelah dicampur dengan sari warna.

- Pisau cutter, yang berfungsi untuk memotong bagian-bagian yang akan dilobangi pada bidang klise. Pada bagian yang berlobang inilah sebagai tempat mengalirkan cat/tinta dalam proses cetak.

- Busa, yang digunakan untuk 'mencocol' cat/tinta, dalam proses pemberian warna diatas permukaan bidang yang akan dicetak. Pemberian warna ini dapat juga dilakukan dengan cara 'menyemburkan' bahan pewarna pada bidang cetakan.

\section{Metode fotografis/afdruk}

Setelah ditemukannya obat afdruk dan gasa screen, metode pengerjaan dalam proses cetak dengan teknik serigrafi ini, semakin berkembang. Disamping dapat membuat cetakan yang lebih banyak dengan memanfaatkan waktu yang lebih efisien, juga mendapatkan hasil cetakan yang lebih halus dan akurasi yang tinggi. 
Dengan perkembangannya yang pesat, serta memegang peranan yang cukup penting di bidang industri dan perusahaan, sehingga media 'silk screen printing' dengan metode fotografis ini semakin diminati sebagai media reproduksi dalam bidang percetakan. Minat terhadap media reproduksi cetak ini, tidak hanya dalam bidang industri modern yang bersifat komersil saja, tapi juga dimanfaatkan sebagai media dalam menciptakan karya seni murni (fine art).

Dengan berkembangnya teknologi komputer dewasa ini, menjadikan para pekerja seni khususnya seniman grafis semakin 'bergairah', dalam menciptakan karya-karya melalui media 'silk screen printing' khususnya melalui metode fotografis ini. Karena dengan metode tersebut, para pekerja seni lebih leluasa dan bebas berkreasi dan berekspresi. Disamping itu, dengan metode fotografis ini, seniman dapat membuat karya dengan memadukan beberapa obyek (image) yang sudah ada kedalam sebuah karya yang direncanakan.

Hanya saja dengan metode fotografis ini memang sedikit lebih rumit dan harus menjalani beberapa proses, yang diawali dari perancangan atau rencana karya yang akan dibuat sampai ke proses pencetakan. Unsur-unsur rupa yang akan diterapkan dalam karya, dapat dibuat secara manual, atau dapat juga menggunakan gambar-gambar (image) yang sudah ada. Selanjutnya, dari rancangan karya tersebut dibuatkan film positif, yang nantinya digunakan sebagai perantara dalam proses penyinaran (afdruk) ke atas permukaan 'screen'. Melalui proses afdruk inilah akan dihasilkan 'klise' sebagai acuan cetak. Oleh karena prosedur yang harus dilakukan melalui proses afdruk inilah, sehingga disebut dengan metode fotografis.

Kelebihan dari pada metode ini adalah, dapat membuat atau menghasilkan karya yang lebih baik, karena unsur-unsur rupa yang diterapkan pada karya dapat dibuat lebih bervariasi dengan akurasi yang tinggi. Disamping itu, dengan metode fotografis ini seniman grafis dapat memanfaatkan gambar-gambar (image) yang sudah ada, tanpa harus membuatnya dengan tangan (manual). Hanya saja, sebagai karya seni murni, calon seniman harus paham tentang konsep berkaryanya, 
meskipun memanfaatkan 'image' yang sudah ada sebagai bagian atau elemen dalam karya yang diciptakan.

Contoh karya

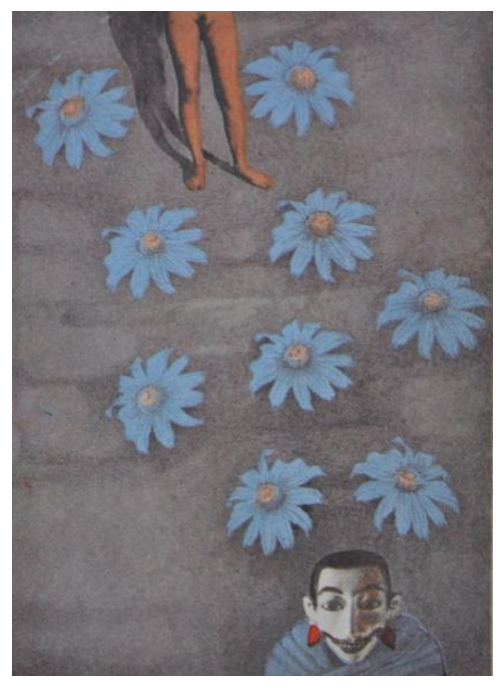

Karya: G. Sidharta

'Khayalan sebuah topeng' (1981) cetak saring (serigraphy) $65 \times 55 \mathrm{~cm}$

Alat dan bahan yang digunakan dalam metode fotografis

- Screen atau gasa screen, adalah alat untuk mencetak gambar (image) pada bidang yang akan dicetak. Gasa screen ini adalah suatu alat berupa bidang yang berpori-pori sangat halus sehingga menyerupai kain sutra. Lubang pori-pori pada gasa screen ini berfungsi menyaring dan menentukan jumlah cat/tinta yang keluar melalui pori-pori. Kerapatan pori-pori gasa screen ini di bagi tiga macam, yaitu screen kasar, cocok untuk media atau bidang cetakan yang menyerap banyak air, seperti kain yang berdasar kaos. Nomor kerapatanya antara $55 \mathrm{~T}$ - 70T ( $\mathrm{T}=$ Thick, satuan kerapatan dan ketebalan benang-benang screen ). Screen sedang, cocok untuk benda yang tidak menyerap banyak air seperti, kertas dan kulit imitasi, nomor kerapatannya antara $90 \mathrm{~T}-120 \mathrm{~T}$. Screen halus, cocok untuk benda yang tidak menyerap air seperti plastik, kaca, mika dan sebagainya, dengan kerapatannya antara $150 \mathrm{~T}-200 \mathrm{~T}$. 


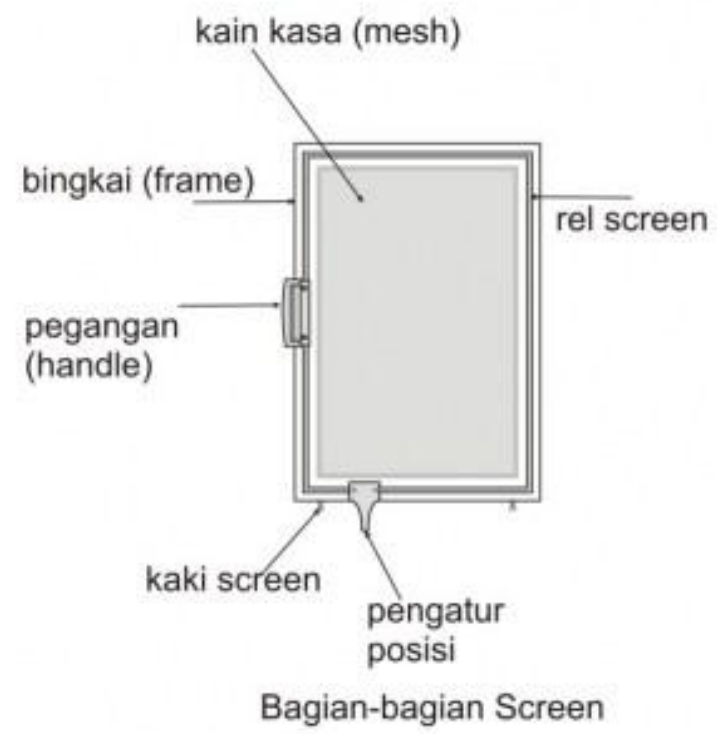

Syarat-syarat screen yang baik adalah :

- Lentur

- Tahan terhadap bahan kimia

- Tahan air panas

- Mudah dibersihkan

- Diameter benang anyaman kecil

- Anyaman kain tidak bergeser

- Film positif, merupakan bidang transparan yang digambar sesuai rancangan karya, yang nantinya digunakan sebagai perantara dalam proses penyinaran (afdruk) di atas permukaan 'screen'.

- Rakel, merupakan alat yang digunakan untuk menerapkan/menekankan cat atau tinta dari bagian dalam screen terhadap bidang cetakan yang berada dibawahnya. Rakel ini umumnya di buat dengan bahan sintetik seperti Polyrethane atau Polyviyl. Bahan ini cukup kuat dan tahan akan kelembaban udara sehingga akan lebih awet. Adapun jenis rakel sesuai fungsinya seperti rakel lunak untuk yang memerlukan banyak tinta, rakel keras untuk hasil yang 
detil dan halus. Bentuk ujung rakel pun ada beberapa jenis, seperti rakel tumpul. rakel bulat, rakel lancip, rakel lancip ujung datar, rakel miring dan rakel kotak.

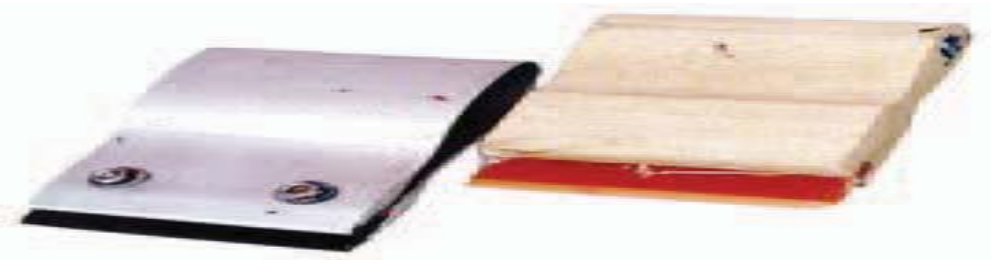

- Meja digunakan sebagai alas atau dasar penempatan lembaran bidang yang akan dicetak

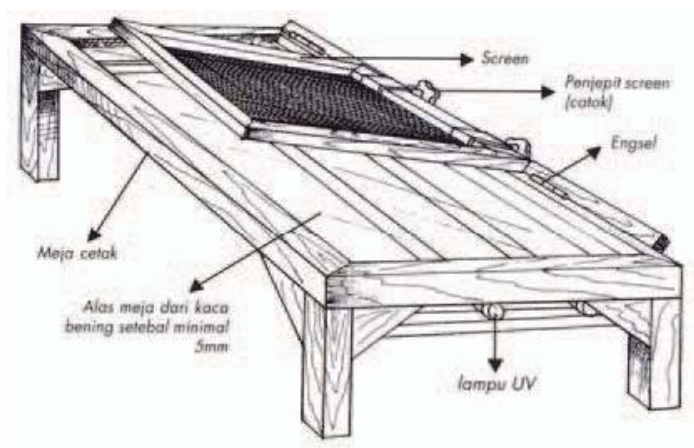

\section{- Engsel 'Catok' (engsel penyekat/ penjepit screen)}

Engsel Catok ini sebagai alat untuk menghubungkan alat cetak (bingkai screen) dengan meja pencetak. Catok ini berfungsi sebagai penggerak yang dapat menjamin kestabilan posisi hasil cetak, terutama pada tahap penyusunan warna. Gerakan-gerakan catok yang menjadikan gerak naik turunnya screen adalah tubuh catok yang melekat pada punggung catok.

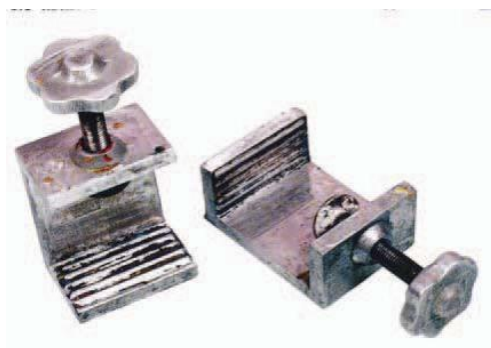

Keuntungan-keuntungan menggunakan engsel catok, antara lain;

1. Bingkai screen tetap berada pada kedudukan asal 
2. Proses cetak dapat berlangsung cepat

3. Kedudukan hasil cetak tetap stabil

4. Hasil cetakan dapat stabil

- Kipas angin sebagai alat penunjang di perlukan untuk membantu mempercepat pengeringan lapisan afdruk pada proses pembuatan klise, Alat ini dapat digantikan dengan hairdryer. Hairdryer akan membantu lebih cepat dibandingkan dengan kipas angin karena selain memanfaatkan angin dari hairdryer juga dapat memanaskan sehingga proses pengeringan akan lebih cepat.

- Handspray, alat ini digunakan untuk membersihkan model gambar atau 'klise' pada screen yang sudah di afdruk.

\section{Bahan Pracetak}

Bahan yang di gunakan dalam proses afdruk untuk pembuatan 'klise'. Adapun bahannya sebagai berikut:

- Larutan afdruk merupakan cairan emulsi dan sensitizer (bahan peka cahaya) perbandingan campuran kedua bahan tersebut sekitar $9: 1$. Contoh beberapa produk bahan afdruk yang berada di pasaran antara lain Ulano, Photosol, Autosol, Chromatin dan sebagainya.

- Krim deterjen ini digunakan sebagai bahan peluruh sisa-sisa cat dan tinta yang masih tertinggal pada screen .

- Bayclean atau bahan pemutih yang digunakan untuk menghapus lapisan afdruk setelah screen selesai digunakan.

\section{Bahan Cetak}

Bahan cetak yang dimaksud disini adalah cat/tinta cetak dan pengencer. Cat/tinta cetak digunakan sebagai materi pokok pembentuk gambar pada sasaran atau media yang akan dicetak. Pengencer digunakan untuk pencampur cat/tinta agar kekentalan dapat disesuaikan. 


\section{Jenis cat/tinta berdasarkan pengencernya}

Cat/tinta yang berbasiskan air disebut dengan cat/tinta Water Base, artinya jika mencetak dengan cat/tinta ini diencerkan atau dicampur dengan air. Sedangkan dengan cat/tinta yang berbasis minyak disebut cat/tinta Solvent Base, yaitu cat/tinta yang menggunakan minyak sebagai pengencernya.

Tahapan-tahapan pada metode fotografis

Ada pun tahapan-tahapan yang harus dilalui dalam proses cetak dengan metode fotografis ini adalah sebagai berikut:

\section{Membuat Rancangan Karya}

Sebelum berkarya tentunya harus memiliki rancangan atau rencana dari karya yang akan dibuat. Rancangan ini berupa gambar (image) ataupun text yang menjadi elemen dalam karya yang akan dibuat. Rancangan karya ini dapat dibuat dengan cara manual ataupun digital. Untuk rancangan manual biasanya menggunakan tinta hitam dibuat di atas kertas kalkir atau lembaran plastik transparan, ketentuan dalam rancangan adalah kepekatan tinta dan gambar harus merata di atas permukaan bidang transparan tersebut. Sedangkan jika pembuatan rancangan melalui proses digital dapat dikerjakan dengan bantuan komputer memanfaatkan software grafis seperti Photoshop, atau Corel Draw. Hasil olahan gambar ini kemudian di Print di atas kertas kalkir dengan warna hitam putih. Adapun alternatif lain sebagai pengganti kertas kalkir adalah dengan menggunakan kertas HVS, dan setelah gambar selesai (sebaiknya di fotocopy), selanjutnya dioleskan dengan minyak kelapa. Hal ini berfungsi untuk menjadikannya 'transparan', sehingga sinar dapat menembus lewat kertas yang sudah transparan tersebut pada proses afdruk.

\section{Proses afdruk}

Proses afdruk, adalah proses pemindahan gambar (image) ke atas permukaan screen dengan menggunakan cahaya ultra violet. Bahan yang dipergunakan, 
sebagaimana sudah disebutkan di atas adalah larutan emulsi dan sensitizer. Proses afdruk dimulai dari melarutkan cairan emulsi dengan sensitizer dengan perbandingan 9:1 yang kemudian dioleskan secara merata pada permuakaan screen. Kemudian screen dikeringkan dengan memakai kipas angin atau hairdryer. Tahapan/proses ini dilakukan diruang gelap untuk menghindari sinar UV mengenai lapisan afdruk, karena jika kena sinar UV dapat diyakinkan proses ini akan gagal. Setelah proses pengeringan lapisan afdruk ini selesai, segera dilakukan proses penyinaran dengan merapatkan permukaan 'film' (gambar motif di atas kertas transparan) atau rancangan yang telah dibuat dengan menggunakan kertas kalkir tadi. Diatas 'film' dihimpit dengan kaca bening, agar 'film' tidak bergeser pada waktu penyinaran. Pada bagian belakang screen disisipkan busa/spon dan kain berwarna gelap untuk mengurangi atau meredam sinar UV. Setelah lebih-kurang 20 detik, screen dipisahkan dari peralatan lainnya dan langsung dibasahi dengan air. Pada proses ini disebut dengan proses pengembangan, setelah dibasahi dengan air dan larutan obat afdruknya telah bersih, dibiarkan kering, atau menggunakan hair dryer untuk mempercepat proses pengeringan sebelum dipakai untuk mencetak.

\section{Proses Cetak}

Persiapan dalam proses mencetak, adalah pemasangan screen pada meja/landasan cetak, setelah screen terpasang dengan tepat barulah dimulai dengan proses pemberian cat/tinta di atas permukaan bidang cetakan dengan bantuan 'rakel'. Dalam proses pewarnaan diusahakan untuk mendahulukan warna yang terang dan dilanjutkan ke warna gelap, setelah cat dipulaskan dengan sedikit penekanan secara merata menggunakan rakel, selanjutnya screen diangkat/dipisahkan dari kertas cetakan yang berada dibawahnya. Kemudian kertas cetakan dikeringkan sebelum melanjutkan kewarna yang lainnya. 


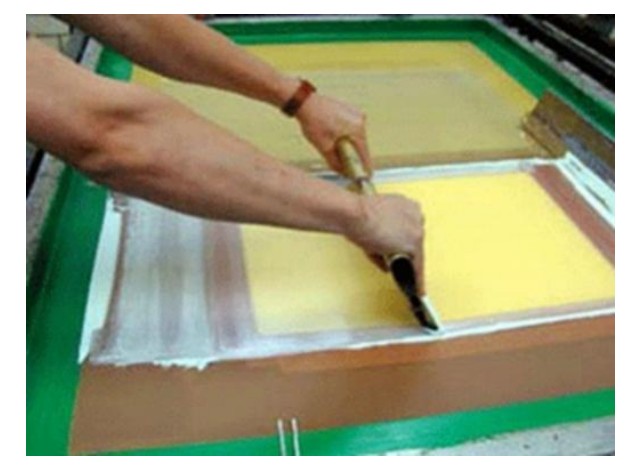

\section{Metode blok/colet}

Metode blok/colet adalah merupakan cara yang secara ekspresif benar-benar datang dari seniman yang bersangkutan. Pada metode ini seniman dapat menuangkan imajinasinya langsung diatas permukaan bidang 'screen' yang digunakan. Unsur-unsur seni rupa yang akan diterapkan pada bidang karya yang akan dibuat, dilakukan dengan cara membuat 'blok' atau dengan 'mencolet'. Dalam hal ini siseniman mengerjakannya langsung di atas permukaan 'screen' yang akan digunakan sebagai acuan (klise) dalam proses mencetak nantinya.

Untuk mendapatkan kualitas dari unsur-unsur visual yang ingin diterapkan dalam sebuah karya sekaligus hasil yang maksimal, calon seniman biasanya menggunakan berbagai macam dan jenis peralatan, misalnya; untuk menampilkan garis-garis yang halus, dapat menggunakan mata 'pen' yang tidak terlalu tajam pada bagian ujungnya, atau menggunakan kuas untuk menampilkan unsur bidang dalam proses pencoletan.

Pemberian 'blok' atau pencoletan ini dilakukan setiap pergantian warna yang akan digunakan dalam proses berkarya. Biasanya dalam metode blok/colet ini, pemberian masing-masing warna, harus dilakukan terhadap semua lembaran cetak sesuai dengan jumlah cetakan yang sudah direncanakan sebelumnya. Dalam hal ini klise (acuan cetak) hanya berlaku untuk satu rancangan karya bagi seniman yang bersangkutan. Dalam hal ini, pemberian warna menggunakan cara dengan pendekatan 'reduksionis'.

Sebagaimana sudah dijelaskan dalam uraian sebelumnya, pada dasarnya, pembuatan klise (acuan cetak) dalam karya seni grafis dapat saja dilakukan sebanyak jumlah warna yang dituntut dalam sebuah karya (dengan menerapkan 
teknik pewarnaan multi-klise), dengan maksud karya tersebut dapat dicetak ulang. Namun biasanya bagi seniman grafis, hal tersebut jarang dilakukan. Salah satu alasannya adalah untuk menjaga 'eksklusif' atau 'nilai' sebuah karya seni grafis dalam konteks seni murni (fine art).

\section{Contoh karya}

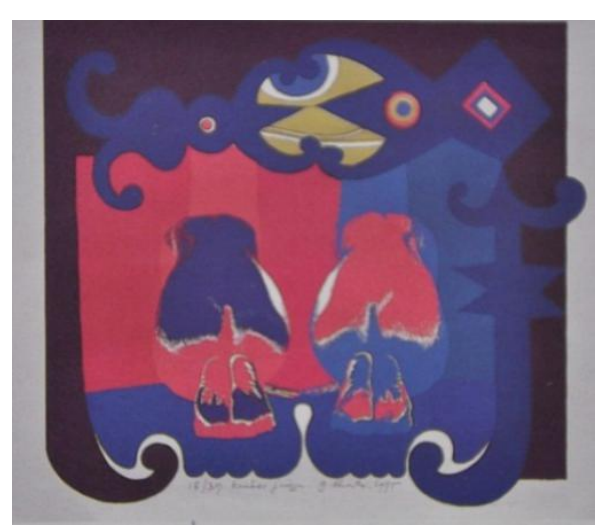

Karya: G. Sidharta

'Kembar Jingga' (1975)

cetak saring (serigraphy) $75 \times 65 \mathrm{~cm}$

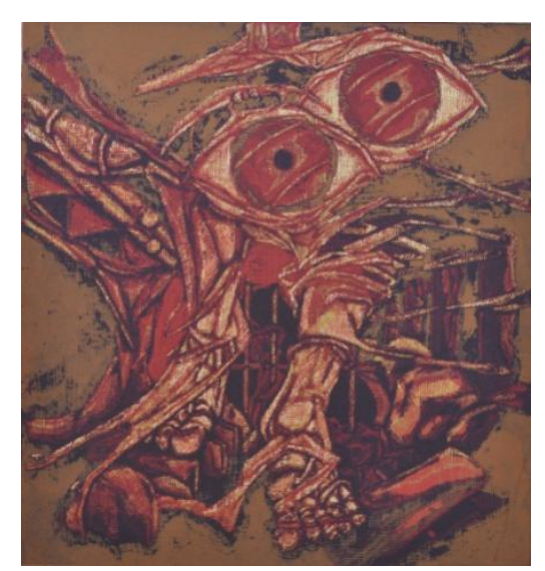

Karya: Ariusmedi

'matakaki' .. (1986)

cetak saring (serigraphy) $55 \times 50 \mathrm{~cm}$ 


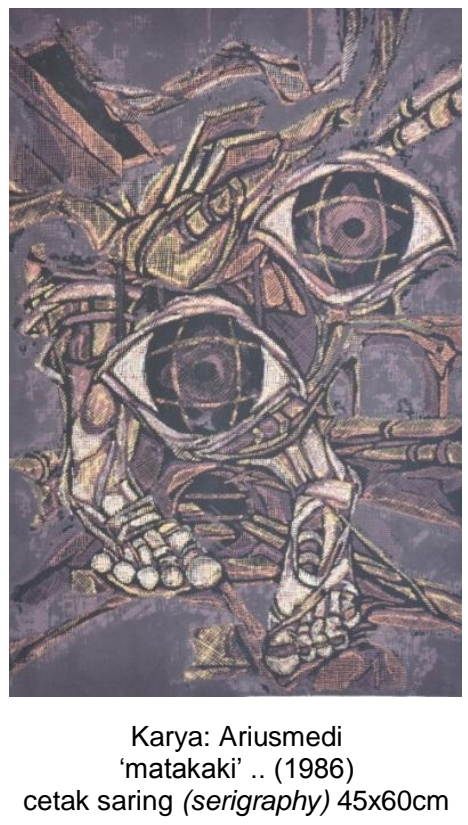

\begin{abstract}
Alat dan bahan yang digunakan
Alat dan bahan yang digunakan dalam metode blok/colet ini, pada dasarnya tidak jauh berbeda dengan peralatan dan bahan yang digunakan dalam metode fotografis/afdruk. Hanya saja, pada metode blok/colet ini tidak lagi memerlukan film positif, karena tidak lagi melalui proses afdruk untuk membuat acuan cetaknya (klise). Dalam proses pembuatan klise (acuan cetak) dalam metode blok/colet seniman (penggrafis) dapat melakukannya secara langsung di atas permukaan screen.
\end{abstract}

\title{
Metode kombinasi
}

Seniman grafis atau calon seniman biasanya tidak atau belum merasa puas hanya dengan satu cara/metode saja dalam rancangan karyanya. Sebagai sosok yang kreatif seniman selalu mencari dan mencoba berbagai kemungkinan dalam berkarya, diantaranya dengan memadukan beberapa macam metode dalam satu karya, misalnya; metode fotografis yang dipadukan dengan metode blok/colet. Hal ini dilakukan, disamping ingin menampilkan karya yang lebih bervariasi, sekaligus melatih kepekaan calon seniman dalam menyikapi perkembangan teknologi yang dapat dimanfaatkan dalam berkarya seni. Tentang obyek karya, calon seniman dapat saja mengkombinasikan beberapa obyek visual atau 
memanfaatkan gambar-gambar (image) yang sudah ada, yang mungkin didapatkan dari hasil foto, atau potongan-potongan gambar yang dirasa cocok dan sesuai dengan konsepnya dalam berkarya. Demikian juga halnya dalam mengkombinasikan teknik dalam satu rancangan karya.

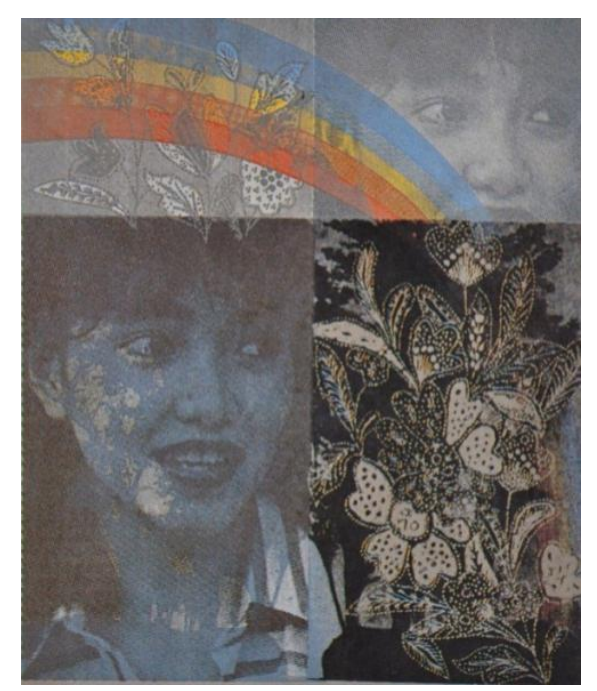

Karya: G. Sidharta

'Sesembungan' (1980)

cetak saring (serigraphy) $65 \times 55 \mathrm{~cm}$

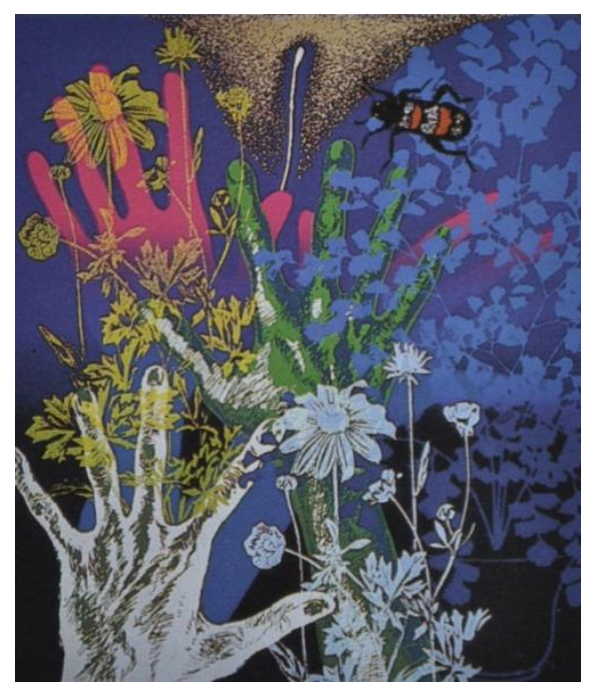

Karya: G. Sidharta

'Gapai-gapai' (1977)

cetak saring (serigraphy) $65 \times 55 \mathrm{~cm}$

Sebagaimana halnya dengan media seni rupa yang lain, hasil akhir dari proses kerja dalam teknik serigrafi ini lebih banyak ditentukan oleh si senimannya sendiri. Untuk dapat menghasilkan karya seni yang baik, si seniman harus dapat 
memanfaatkan segala potensi kesenirupaannya. Memanfaatkan unsur-unsur dalam seni rupa serta memahami konsep-konsepnya.

\section{Unsur-unsur Seni Rupa}

Karya seni rupa terwujud dari unsur-unsur pembentuk yang dapat dilihat secara visual dan dinikmati secara fisik (seperti diraba), sekaligus memberi perasaan batin tertentu bagi pengamatnya. Unsur-unsur pembentuk karya seni rupa terdiri atas unsur fisik yang dapat dilihat dan unsur non fisik.

\section{Unsur-unsur Fisik Seni Rupa}

Unsur-unsur fisik yang membentuk suatu karya seni rupa, diantaranya;

Garis, merupakan unsur atau elemen yang paling mendasar dalam mewujudkan sebuah karya seni rupa.

Bidang, terwujud dari garis yang bersambung ujung-ujungnya, misalnya; bidang lingkaran. Bidang juga dapat timbul dari kesan yang dibentuk oleh pulasan warna. Bentuk, unsur bentuk selalu berkaitan dengan benda tiga dimensi, baik alami maupun buatan.

Ruang, unsur ruang dapat berwujud dua atau tigadimensi, sehingga dapat memiliki kesan panjang, kedalaman, lebar dan sebagainya.

Tekstur, berdasarkan wujudnya dapat dibedakan antara tekstur asli dan tekstur buatan. Tekstur asli merupakan tekstur nyata yang dapat dirasakan dengan dilihat dan diraba. Sedangkan tekstur buatan hadir pada bidang dua dimensi; melalui pengolahan warna, ruang, nada, garis dan sebagainya, sehingga menimbulkan kesan tertentu pada mata pengamat.

Warna, merupakan kesan yang ditimbulkan akibat pantulan cahaya yang menimpa permukaan suatu benda.

\section{Unsur-unsur Non-Fisik Seni Rupa}

Adanya unsur-unsur non-fisik seni rupa memerlukan kaidah atau aturan baku untuk menyusunnya, hingga terbentuk sebuah karya seni yang indah dan menarik. 
Kaidah yang berkaitan erat dengan nilai-nilai estetika dinamakan komposisi. Komposisi mencakup tiga hal pokok, yakni;

Kesatuan, paduan unsur-unsur visual dengan karakter yang berbeda harus hadir dalam satuan yang saling mengisi. Kesatuan dari berbagai unsur ini akan menunjang terciptanya karya seni yang sempurnadan berkualitas indah.

Keseimbangan, adalah adanya rasa kesamaan dari unsur-unsur yang berlawanan, tetapi saling memerlukan karena dapat menciptakan satu kesatuan. Keseimbangan secara estetis adalah keseimbangan yang lebih mementingkan nilai, bukan hanya pada bentuk atau ukuran yang sama.

Irama, adalah kesan gerak yang timbul dari keselarasan unsur-unsur seni rupa yang tersusun dalam sebuah komposisi. Rangkaian Harmoni/kontras, pengulangan dan variasi, adalah beberapa cara dalam menciptakan irama pada sebuah karya seni rupa. 


\section{Buku Ajar}

Bahan Kajian

SKS

Program Studi

Pertemuan Ke

Dosen
: Seni Grafis 2 (serigraphy)

: 3 (tiga)

: Pendidikan Seni Rupa

: 3-4

: Drs. Ariusmedi, M.Sn.

Drs. Irwan, M.Sn.

\section{Learning Outcomes (Capaian Pembelajaran) terkait KKNI}

Ruang Lingkup Seni Grafis khususnya pada teknik Serigraphy

a. Prinsip kerja pada metode pola potong sebagai salah satu metode dalam teknik Serigraphy.

b. Merancang pola-pola sederhana dengan metode pola potong sebagai salah satu alternatif dalam berkarya seni

Soft skills/Karakter: Terampil mengaplikasikan potensi seni rupa dalam metode cetak sederhana menurut kaedah serta konsep berkesenian.

\section{Bagian 2}

Praktek Studio 1

\section{Materi :}

a. Prinsip kerja dan rangkaian proses dalam metode pola potong

b. Membuat rancangan sederhana dengan metode pola potong

c. Mengolah klise dan melakukan proses cetak

\section{Pengantar}

Tujuan yang ingin dicapai dalam pembelajaran pada kerja praktek studio ini adalah, disamping dapat mengaplikasikan potensi keseni-rupaan yang dimiliki oleh mahasiswa, juga dapat lebih memahami prinsip kerja dari pada metode pola potong sebagai salah satu metode dalam teknik serigraphy.

\section{Penyajian/Uraian Materi}

Metode pola potong.

Meskipun cara ini merupakan metoda tertua dan primitif, namun sampai sekarang masih dimanfaatkan untuk mengerjakan berbagai keperluan, misalnya; 
untuk pemberian merek-merek atau lambang-lambang pada suatu produk dalam bidang industri dan perusahaan tertentu. Dalam kontek berkarya seni grafis bagi mahasiswa, metode sederhana ini perlu dilaksanakan untuk mengawali pemahaman tentang proses kerja dari teknik cetak serigrafi ini. Mengingat metode pola potong ini, hanya terbatas pada obyek gambar (motif) yang sederhana, sehingga perlu dipikirkan masalah rancangan karya yang sesuai dengan kapasitas yang ada pada metode ini. Dalam rancangan karya diusahakan menghindari penerapan unsur-unsur rupa yang rumit seperti garis-garis yang terlalu halus, atau penerapan warna yang terlalu banyak dan sebagainya.

Tugas praktek dalam metode pola potong ini, diarahkan pada perancangan karya seni grafis dengan pola-pola sederhana yang menghasilkan karya utuh, yang diawali dengan pembuatan sketsa, pemindahan sketsa ke atas permukaan 'klise' dan proses cetak.

\section{Peralatan dan bahan yang diperlukan:}

- Kertas karton manila atau plastik transparan sebagai bahan dasar 'klise'

- Pisau 'cutter', untuk memotong bagian-bagian motif/pola yang diinginkan sebagai penghasil gambar, sesuai dengan rancangan karya

- Kertas gambar A-3, sebagai bidang/lembaran yang akan dicetak

- Cat/tinta cetak berbasis air (seperti; cat tembok, cat poster dsb)

- Busa, untuk penghantar cat/tinta yang digunakan (pada teknik 'cocol'), atau 'handsprayer' untuk teknik sembur. 


\section{Buku Ajar}

Bahan Kajian

SKS

Program Studi

Pertemuan Ke

Dosen
: Seni Grafis 2 (serigraphy)

: 3 (tiga)

: Pendidikan Seni Rupa

: $5-8$

: Drs. Ariusmedi, M.Sn.

Drs. Irwan, M.Sn.

\section{Learning Outcomes (Capaian Pembelajaran) terkait KKNI}

Ruang Lingkup Seni Grafis khususnya pada teknik Serigraphy

a. Prinsip kerja pada metode fotografis sebagai salah satu metode dalam teknik Serigraphy.

b. Pengetahuan dalam penerapan teknologi sebagai media penciptaan karya seni yang inovatif.

c. Membuat karya seni grafis dengan memadukan unsur-unsur seni rupa yang menghasilkan karya secara utuh, diawali dengan pembuatan rancangan karya, pembuatan 'film positif', proses afdruk sampai ke proses pencetakan.

Soft skills/Karakter: Terampil mengaplikasikan potensi seni rupa serta penerapan teknologi dalam penciptaan karya seni murni.

\section{Bagian 3}

Praktek Studio 2

\section{Materi :}

a. Prinsip kerja dan rangkaian proses dalam metode fotografis

b. Pengetahuan serta penerapan teknologi dalam berkarya seni murni

c. Memahami tentang konsep-konsep dan kaedah dalam berkesenian

\section{Pengantar}

Setelah ditemukannya obat afdruk dan gasa screen, cara pengerjaan dalam proses cetak dengan teknik serigrafi ini, semakin berkembang. Karena dengan adanya obat afdruk dan gasa screen inilah, mahasiswa dapat lebih leluasa serta bebas berkreasi dan berekspresi. Disamping itu, dengan metode fotografis/afdruk 
ini, mahasiswa dapat membuat karya dengan memadukan beberapa obyek (image) yang sudah ada kedalam sebuah karya yang direncanakan.

\section{Penyajian/Uraian Materi}

\section{Metode fotografis/afdruk}

Metode fotografis/afdruk ini pengerjaannya memang sedikit lebih rumit dan harus menjalani beberapa proses, yang diawali dari perancangan atau rencana karya yang akan dibuat, membuatkan film positif, yang nantinya digunakan sebagai perantara dalam proses penyinaran (afdruk) ke atas permukaan 'screen'. Melalui proses afdruk inilah akan dihasilkan 'klise' sebagai acuan cetak.

Unsur-unsur rupa yang akan diterapkan dalam karya, dapat dibuat secara manual, atau dapat juga menggunakan gambar-gambar (image) yang sudah ada. Hanya saja, dalam konteks penciptaan karya seni murni, mahasiswa, baik sebagai calon guru maupun sebagai calon seniman grafis harus paham tentang konsep berkaryanya, meskipun memanfaatkan 'image' yang sudah ada sebagai elemen atau unsur-unsur dalam karya yang diciptakan.

Tujuan yang ingin dicapai dalam pembelajaran pada kerja praktek studio, dengan menerapkan metode fotografi/afdruk ini, disamping dapat mengaplikasikan potensi keseni-rupaan yang dimiliki oleh mahasiswa, sekaligus pengetahuan dalam menerapkan teknologi sebagai media penciptaan karya seni yang inovatif.

Tugas praktek dalam metode fotografi/afdruk ini, diarahkan pada perancangan karya seni grafis dengan memadukan unsur-unsur seni rupa yang menghasilkan karya secara utuh, yang diawali dengan pembuatan rancangan karya, pembuatan 'film positif', proses afdruk sampai ke proses pencetakan.

\section{Peralatan dan bahan yang diperlukan:}

- Gasa screen (monyl) dengan ukuran/nomor kerapatan antara 90T - 120T sebagai bahan utama pembuatan 'klise'

- Rakel, yang digunakan untuk pemulasan/penekan cat pada proses pencetakan karya

- Kertas gambar A-2, sebagai bidang/lembaran yang akan dicetak 
- Tinta cetak saring

Komponen tinta terdiri dari bahan pewarna, bahan pengikat (vernis), pelarut dan bahan penolong sesuai dengan kebutuhan. Berdasarkan komposisi tinta tersebut, tinta cetak ssaring dapat dikelompokkan sebagai berikut:

Tinta cetak yang campuran vernisnya adalah minyak dan resin (oil based ink)

Tinta cetak yang campuran vernisnya adalah pelarut dan resin (solvent based ink)

Tinta cetak yang campuran vernisnya resin dengan air (water based ink)

Dalam prateknya penggunaan tinta disesuaikan dengan bahan cetak. Dalam pencampurannya dapat dilakukan sesaat atau sebelum digunakan dengan perbandingan tertentu.

Hal-hal yang harus diperhatikan untuk menentukan tinta yang akan digunakan adalah:

a. Bagaimana pengaruh tinta terhadap kain kasa

b. Bagaimana pengaruh tinta terhadap cahaya

c. Bagaimana ketahanan tinta terhadap zat pelarut

d. Bagaimana kemampuaan daya rekat tinta terhadap benda yang disablon.

- Bahan obat afdruk

Bahan afdruk digunakan untuk proses pembuatan gambar pada screen bila pembuatan gambar melalui foto copy/foto kimia. Bahan afdruk berfungsi untuk menutup screen pada bidang bukan gambar.

Ulano 133, pemakaian dicampur dengan sensitizer yang ada dalam kemasan untuk cetak menggunakan tinta dengan dasar minyak.

Ulano TZ, digunakan untuk tinta berbasis air

- Bahan penghapus/ bahan pembersih

Bahan penghapus atau bahan pembersih digunakan untuk membersikan bahan afdruk pada screen agar screen bersih kembali dan dapat digunakan untuk pekerjaan baru (rancangan karya yang baru) 
Jenis-jenis bahan penghapus:

Ulano 6 berfungsi untuk menutup screen yang bocor serta menggunakan tinta dengan dasar minyak

Ulano 8 berfungsi untuk menghapus banyangan gambar (ghosting) pada screen. Dapat juga menggunakan Fujisol atau M3.

Ulano 3 berfungsi membersikan screen dari lemak dan debu

Ulano 23 berfungsi untuk membesikan debu dan lemak sekaligus mengasarkan screen agar bahan afdruk dapat terikan dengan erat di atas kain screen.

Bahan penguat berfungsi sebagai menguatkan sekaligus melindungi bahan afdruk dipermukaan screen sehingga cairan emulsinya tidak cepat rusak baik karena terkikis oleh rakel maupun oleh karena bereaksi dengan tinta yang digunakan. Biasanya bahan yang digunakan adalah ulano X, dan ulano G.

Proses pemindahan gambar dalam metode fotografi/afdruk

Proses pemindahan gambar dilakukan di ruang gelap, proses pemindahan gambar dilakukan dengan proses kimia. Bahan-bahan kimia yang digunakan untuk proses afdruk adalah ulano 133 yang digunakan untuk cetakan yang menggunakan tinta yang berbasis minyak, dan Ulano TZ untuk mencetak menggunakan tinta yang berbasis air.

Sebelum dilakukan proses afdruk, screen haruslah ditutup menggunakan ulano dengan merata sehingga hasil pengafdrukan sempurna. Gunakanlah ulano sesuai dengan areal/objek gambar-gambar yang akan dipindahkan sehingga tidak memakan biaya yang banyak. Setelah screen ditutup dengan menggunakan ulano secara merata dan dikeringkan. Selanjutnya, dilakukan penyinaran dengan memanfaatkan sinar matahari. Proses selanjutnya adalah membilas atau 'penyemprotan' dengan air, sehingga menghasilkan 'klise' dimana objek gambar dalam keadaan tembus (terbuka kembali pori-pori anyamannya) dan bagian yang bukan 'area' gambar tetap menutup, karena sudah bereaksi dengan sinar. 
Proses cetak

Proses cetak dilakukan setelah proses afdruk selesai, ambil 'klise' (screen yang sudah diafdruk) serta siapkan bidang/lembaran yang akan dicetak. Pasangkan screen pada meja cetak dengan menggunakan engsel catok. Sediakan tinta yang khusus untuk cetak saring, campur tinta menggunakan larutan pengencer di wadah terpisah sehingga tinta menjadi agak encer. Tuangkan tinta ke screen secukupnya, lalu dicetak ke atas lembaran yang diinginkan. 


\section{Buku Ajar}

Bahan Kajian

SKS

Program Studi

Pertemuan Ke

Dosen
: Seni Grafis 2 (serigraphy)

: 3 (tiga)

: Pendidikan Seni Rupa

: 10-13

: Drs. Ariusmedi, M.Sn.

Drs. Irwan, M.Sn.

\section{Learning Outcomes (Capaian Pembelajaran) terkait KKNI}

a. kemampuan dalam mewujudkan ide kreatif menjadi sebuah karya seni yang bermutu, unik dan tetap menjaga 'orisinalitas' serta 'eksklusif'nya sebagai karya seni murni.

b. Membuat karya seni grafis dengan memadukan unsur-unsur seni rupa yang menghasilkan karya secara utuh, yang diawali dengan pembuatan rancangan karya, pengolahan klise secara langsung dalam metode blok/colet sampai ke proses pencetakan.

Soft skills/Karakter: Terampil mengaplikasikan potensi seni rupa serta penggunaan bahan dan alat dalam penciptaan karya seni murni.

\section{Bagian 4}

Praktek Studio 3

\section{Materi :}

a. Prinsip kerja dan rangkaian proses dalam metode blok/colet

b. Pengetahuan tentang bahan dan alat serta penerapannya dalam karya seni murni

c. Memahami tentang konsep-konsep dan kaedah dalam berkesenian

\section{Pengantar}

Tujuan yang ingin dicapai dalam pembelajaran pada kerja praktek studio 3 dengan metode blok/colet ini, disamping dapat mengaplikasikan potensi kesenirupaan yang dimiliki oleh mahasiswa, sekaligus mengasah kemampuan mahasiswa dalam mewujudkan ide kreatif menjadi sebuah karya seni yang baik, unik dan tetap menjaga 'orisinalitas' serta 'eksklusif' nya sebuah karya seni grafis. 


\section{Penyajian/Uraian Materi}

\section{Metode blok/colet}

Pada metode ini mahasiswa dapat menuangkan imajinasinya langsung diatas permukaan bidang 'screen' yang digunakan. Unsur-unsur seni rupa yang akan diterapkan pada bidang karya yang akan dibuat, dilakukan dengan cara membuat 'blok' atau dengan 'mencolet'. Dalam hal ini mahasiswa mengerjakannya langsung di atas permukaan 'screen' yang akan digunakan sebagai acuan (klise) dalam proses mencetak nantinya.

Untuk mendapatkan kualitas dari unsur-unsur visual yang ingin diterapkan dalam sebuah karya sekaligus hasil yang maksimal, dapat menggunakan berbagai macam dan jenis peralatan, misalnya; untuk menampilkan garis-garis yang halus, dapat menggunakan mata 'pen' yang tidak terlalu tajam pada bagian ujungnya, atau menggunakan kuas untuk menampilkan unsur bidang dalam proses pencoletan.

Pemberian 'blok' atau pencoletan ini dilakukan setiap pergantian warna yang akan digunakan dalam proses berkarya. Biasanya pada metode blok/colet ini, pemberian masing-masing warna, harus dilakukan terhadap semua lembaran cetak sesuai dengan jumlah cetakan yang sudah direncanakan sebelumnya. Dalam hal ini, klise (acuan cetak) hanya berlaku untuk satu rancangan karya, atau dapat juga dikatakan bahwa, pendekatan 'reduksionis' yang diterapkan dalam pemberian warna pada karya yang dikerjakan.

Tugas praktek dalam metode blok/colet ini, diarahkan pada perancangan karya seni grafis dengan memadukan unsur-unsur seni rupa yang menghasilkan karya secara utuh, yang diawali dengan pembuatan rancangan karya, proses tahapan pembuatan klise sekaligus pewarnaan, sampai kepada proses pencetakan warna terakhir.

\section{Peralatan dan bahan yang diperlukan:}

- Gasa screen (monyl) dengan ukuran/nomor kerapatan antara 70T - 90T sebagai bahan utama pembuatan 'klise' 
- Rakel, yang digunakan untuk pemulasan/penekan cat pada proses pencetakan karya

- Kertas karton manila, untuk membuat pola/motif karya

- Kertas gambar A-2, sebagai bidang/lembaran yang akan dicetak

- Cat/tinta cetak berbasis air (seperti; cat rainbow, fasdey colour dan cat tembok sebagai pencampur, serta sari warna (sesuai dengan warna yang diinginkan)

- Larutan penutup klise (seperti; Ulano TZ, Chromatine dsb), untuk menampilkan motif/pola rancangan di atas permukaan screen.

- Kuas berbagai ukuran dan

- 'mata pen' (yang tidak tajam). 


\section{Buku Ajar}

Bahan Kajian

SKS

Program Studi

Pertemuan Ke

Dosen
: Seni Grafis 2 (serigraphy)

: 3 (tiga)

: Pendidikan Seni Rupa

: $14-16$

: Drs. Ariusmedi, M.Sn.

Drs. Irwan, M.Sn.

\section{Learning Outcomes (Capaian Pembelajaran) terkait KKNI}

a. Mampu menciptakan karya seni dengan memadukan berbagai metode dalam satu karya seni yang utuh, dan tetap menjaga 'orisinalitas' serta 'eksklusif' nya sebuah karya seni grafis dalam konteks seni murni.

b. Membuat karya seni grafis dengan kombinasi beberapa metode yang menghasilkan karya secara utuh, diawali dengan pembuatan rancangan karya, pengolahan klise sampai ke proses pencetakan.

Soft skills/Karakter: Terampil mengaplikasikan potensi seni rupa serta penerapan berbagai metode dalam penciptaan karya seni murni.

\section{Bagian 5}

Praktek Studio 4

\section{Materi :}

a. Prinsip kerja dan rangkaian proses dalam metode kombinasi

b. Pengetahuan tentang bahan dan alat serta penerapannya dalam karya seni murni

c. Memahami tentang konsep-konsep dan kaedah dalam berkesenian

\section{Pengantar}

Mahasiswa biasanya tidak atau belum merasa puas hanya dengan memanfaatkan satu cara/metode saja dalam penciptaan karyanya. Sebagai sosok yang kreatif akan selalu mencari dan mencoba berbagai kemungkinan dalam berkarya, diantaranya dengan memadukan beberapa metode dalam satu karya, misalnya; metode fotografis dengan teknik colet. Hal ini dilakukan, disamping ingin menampilkan karya yang lebih bervariasi, sekaligus melatih kepekaan serta menyikapi perkembangan teknologi yang dapat dimanfaatkan dalam berkarya seni. 


\section{Penyajian/Uraian Materi}

\section{Metode kombinasi}

Tentang obyek karya, mahasiswa dapat saja mengkombinasikan beberapa obyek visual atau memanfaatkan gambar-gambar (image) yang sudah ada, yang mungkin didapatkan dari hasil foto, atau potongan-potongan gambar yang dirasa cocok dan sesuai dengan konsepnya dalam berkarya. Demikian juga halnya dalam mengkombinasikan berbagai metode dalam satu rancangan karya.

Tujuan yang ingin dicapai dalam pembelajaran pada kerja praktek studio 4 dengan cara/metode kombinasi ini, disamping dapat mengaplikasikan potensi keseni-rupaan yang dimiliki oleh mahasiswa, sekaligus mengasah kemampuan mahasiswa menciptakan karya seni yang lebih bervariasi dengan memadukan berbagai metode dalam satu karya seni yang utuh, dan tetap menjaga 'orisinalitas' serta 'eksklusif' nya sebuah karya seni grafis.

Tugas praktek dalam metode kombinasi ini, diarahkan pada perancangan karya seni grafis yang lebih ditekankan pada kemampuan dalam memadukan beberapa metode dalam satu kesatuan karya seni yang dihasilkan, dengan tidak mengabaikan konsep-konsep dalam penciptaan karya. Pelatihan diawali dari pengungkapan ide sampai ke penyelesaian akhir dari sebuah karya. 
Perangkat Perkuliahan

\section{SILABUS}

\section{RANCANGAN PEMBELAJARAN SATU SEMESTER}

Bahan Kajian

SKS

Program Studi

Fakultas

Dosen
: Seni Grafis 2 (Serigraphy)

: 3 sks

: PendidikanSeni Rupa

: Bahasa dan Seni

: Drs. Ariusmedi, M.Sn.

Drs. Irwan, M.Sn.

Learning Outcomes (Capaian Pembelajaran) terkait KKNI

Pengetahuan tentang proses cetak mencetak dua dimensi serta memvisualisasikan ide/gagasan berkarya dalam media Seni Grafis. Mencakup pada ruang lingkup, metode serta pengenalan bahan dan alat dalam proses penciptaan karya. Aplikasi diarahkan pada teknik Serigraphy dengan beberapa metode, yang diiringi dengan pembuatan sketsa sampai terciptanya karya seni secara utuh.

Soft Skils/Karakter: memotivasi diri dan memiliki kemampuan dalam menciptakan karya seni grafis sebagai seni murni.

Matrik Pembelajaran:

\begin{tabular}{|c|l|l|l|l|l|l|}
\hline $\begin{array}{l}\text { Ming } \\
\text {-gu }\end{array}$ & $\begin{array}{c}\text { Learning Outcomes } \\
\text { (Capaian Pembelajaran) } \\
\text { Utama }\end{array}$ & $\begin{array}{c}\text { Pengalaman } \\
\text { Belajar }\end{array}$ & $\begin{array}{c}\text { Materi/Po-kok } \\
\text { Bahasan }\end{array}$ & $\begin{array}{c}\text { Metode Strategi } \\
\text { Pembelajaran }\end{array}$ & $\begin{array}{c}\text { Kriteria/ } \\
\text { Teknik } \\
\text { Penilaian }\end{array}$ & $\begin{array}{c}\text { Daftar } \\
\text { Pustaka }\end{array}$ \\
\hline 1 & 2 & 3 & 4 & 5 & 6 & 7 \\
\hline 1. & $\begin{array}{l}\text { Pengantar Perkuliahan: } \\
\text { Uraian Silabus } \\
\text { Kontrak Perkuliahan } \\
\text {-Ruang Lingkup Sn Grafis } \\
\text {-Teknik dalam Seni } \\
\text { Grafis }\end{array}$ & $\begin{array}{l}\text { Mendengarkan } \\
\text { Melihat dan } \\
\text { Mendiskusi- } \\
\text { kan }\end{array}$ & $\begin{array}{l}\text { Sejarah } \\
\text { perkembangan } \\
\text { Seni Grafis. } \\
\text { Ruang } \\
\text { lingkup. } \\
\text { Karakteristik } \\
\text { serta manfaat } \\
\text { berkarya. }\end{array}$ & $\begin{array}{l}\text { Ceramah, } \\
\text { diskusi dan } \\
\text { tanya jawab }\end{array}$ & $\begin{array}{l}\text { Sikap dan } \\
\text { respon dlm } \\
\text { melakukan } \\
\text { diskusi }\end{array}$ & $\begin{array}{l}\text { Silabus } \\
\text { dan } \\
\text { Buku } \\
\text { ajar }\end{array}$ \\
& & & & & \\
\end{tabular}




\begin{tabular}{|c|c|c|c|c|c|c|}
\hline 2. & $\begin{array}{l}\text {-Pengertian Serigraphy } \\
\text {-Metode dalam } \\
\text { Serigraphy } \\
\text {-Pengetahuan tentang } \\
\text { Bahan dan Alat }\end{array}$ & $\begin{array}{l}\text { Mendengarkan } \\
\text { Melihat dan } \\
\text { Mendiskusi- } \\
\text { kan }\end{array}$ & $\begin{array}{l}\text { Pemahaman, } \\
\text { metode dlm } \\
\text { teknik seri- } \\
\text { graphy. } \\
\text { Pengetahuan } \\
\text { tentang bahan } \\
\text { dan alat }\end{array}$ & $\begin{array}{l}\text { Ceramah, } \\
\text { diskusi dan } \\
\text { tanya jawab }\end{array}$ & $\begin{array}{l}\text { Sikap dan } \\
\text { respon dlm } \\
\text { melakukan } \\
\text { diskusi }\end{array}$ & $\begin{array}{l}\text { Buku } \\
\text { ajar, } \\
\text { hal. 4- } \\
15\end{array}$ \\
\hline 3. & $\begin{array}{l}\text { Pengantar Tugas } 1 \\
\text {-Metode pola potong } \\
\text {-Rancangan karya } \\
\text {-Konsep berkarya } \\
\text {-Assitensi Rancangan }\end{array}$ & $\begin{array}{l}\text { Mendengarkan } \\
\text { Melihat dan } \\
\text { Membuat } \\
\text { Rancangan } \\
\text { Karya }\end{array}$ & $\begin{array}{l}\text { Tahapan dlm } \\
\text { mengungkap } \\
\text { ide pencipta- } \\
\text { an, konsep } \\
\text { berkarya, serta } \\
\text { tujuan } \\
\text { berkarya }\end{array}$ & $\begin{array}{l}\text { SOP, ceramah, } \\
\text { diskusi dan } \\
\text { resitasi }\end{array}$ & $\begin{array}{l}\text { Tugas dan } \\
\text { rancangan } \\
\text { karya }\end{array}$ & $\begin{array}{l}\text { - Budi- } \\
\text { wirman } \\
\text {-Dwi } \\
\text { Marian } \\
\text { to }\end{array}$ \\
\hline 4. & $\begin{array}{l}\text { Lanjutan tugas } 1 \\
\text {-Keselamatan Kerja } \\
\text {-Pengolahan Klise } \\
\text {-Proses Cetak } \\
\text {-Finishing }\end{array}$ & $\begin{array}{l}\text { Mendengarkan } \\
\text { Melihat dan } \\
\text { Mengolah } \\
\text { klise serta } \\
\text { melakukan } \\
\text { proses cetak }\end{array}$ & $\begin{array}{l}\text { Pengetahuan } \\
\text { tentang } \\
\text { keselamatan } \\
\text { kerja, tahap-an } \\
\text { dlm ber-karya. } \\
\text { Melakukan } \\
\text { cetak seder- } \\
\text { hana }\end{array}$ & $\begin{array}{l}\text { SOP, ceramah, } \\
\text { diskusi dan } \\
\text { resitasi }\end{array}$ & $\begin{array}{l}\text { Tugas dan } \\
\text { pengolah- } \\
\text { an klise, } \\
\text { kebersihan } \\
\text { hasil cetak }\end{array}$ & \\
\hline 5. & $\begin{array}{l}\text { Pengantar Tugas } 2 \\
\text {-Metode Fotografis } \\
\text {-Pengetahuan tentang } \\
\text { Bahan dan Alat } \\
\text {-Rancangan Karya } \\
\text {-Assistensi Rancangan }\end{array}$ & $\begin{array}{l}\text { Mendengarkan } \\
\text { Melihat dan } \\
\text { Membuat } \\
\text { Rancangan } \\
\text { Karya }\end{array}$ & $\begin{array}{l}\text { Tahapan dlm } \\
\text { metode foto- } \\
\text { grafis. } \\
\text { Pengetahuan } \\
\text { ttg bahan \& } \\
\text { alat. Meng- } \\
\text { ungkapkan } \\
\text { ide. Etika } \\
\text { dalam ber- } \\
\text { karya }\end{array}$ & $\begin{array}{l}\text { SOP, ceramah, } \\
\text { diskusi, tanya } \\
\text { jawab dan } \\
\text { resitasi }\end{array}$ & $\begin{array}{l}\text { Ide } \\
\text { penciptaan } \\
\text {-Tugas dan } \\
\text { rancangan } \\
\text { karya }\end{array}$ & $\begin{array}{l}\text {-Anto- } \\
\text { nius } \\
\text { Bowo } \\
\text { - Budi- } \\
\text { wirman }\end{array}$ \\
\hline 6. & $\begin{array}{l}\text { Lanjutan Tugas } 2 \\
\text {-Pembuatan Film Positif } \\
\text {-Proses Afdruk } \\
\text {-Keselamatan Kerja }\end{array}$ & $\begin{array}{l}\text { Mendengarkan } \\
\text { Melihat dan } \\
\text { Mengerjakan } \\
\text { tugas }\end{array}$ & $\begin{array}{l}\text { Pemahaman } \\
\text { ttg film dan } \\
\text { afdruk. } \\
\text { Mengatasi } \\
\text { masalah dlm } \\
\text { proses afdruk }\end{array}$ & $\begin{array}{l}\text { SOP, ceramah, } \\
\text { diskusi } \\
\text { demonstrasi } \\
\text { dan resitasi }\end{array}$ & $\begin{array}{l}\text { Tugas dan } \\
\text { pengolah- } \\
\text { an film, } \\
\text { kebersihan } \\
\text { hasil } \\
\text { afdruk }\end{array}$ & Sda. \\
\hline 7. & $\begin{array}{l}\text { Lanjutan Tugas } 2 \\
\text {-Proses Cetak warna I } \\
\text {-Posisi tepat dalam } \\
\text { mencetak } \\
\text {-Proses Cetak warna II }\end{array}$ & $\begin{array}{l}\text { Mendengarkan } \\
\text { Melihat dan } \\
\text { Mengerjakan } \\
\text { tugas }\end{array}$ & $\begin{array}{l}\text { Melakukan } \\
\text { proses cetak. } \\
\text { Manfaat } \\
\text { engsel catok } \\
\text { dlm proses } \\
\text { banyak warna } \\
\text { (poli chrome) }\end{array}$ & $\begin{array}{l}\text { SOP, ceramah, } \\
\text { diskusi } \\
\text { demonstrasi } \\
\text { dan resitasi }\end{array}$ & $\begin{array}{l}\text { Tugas } \\
\text { hasil cetak, } \\
\text { ketepatan } \\
\& \\
\text { kebersihan } \\
\text { hasil cetak }\end{array}$ & Sda. \\
\hline 8. & $\begin{array}{l}\text { Lanjutan Tugas } 2 \\
\text {-Proses Cetak warna III } \\
\text { dan ke IV } \\
\text {-Finishing }\end{array}$ & $\begin{array}{l}\text { Mendengarkan } \\
\text { Melihat dan } \\
\text { Melanjutkan } \\
\text { tugas }\end{array}$ & $\begin{array}{l}\text { Pengetahuan } \\
\text { tentang } \\
\text { komposisi } \\
\text { warna. } \\
\text { Mengatasi } \\
\text { masalah dlm } \\
\text { proses cetak }\end{array}$ & $\begin{array}{l}\text { SOP, ceramah, } \\
\text { diskusi dan } \\
\text { resitasi }\end{array}$ & $\begin{array}{l}\text { Tugas } \\
\text { hasil cetak, } \\
\text { ketepatan } \\
\& \\
\text { kebersihan } \\
\text { hasil cetak }\end{array}$ & Sda. \\
\hline 9. & Ujian Tengah Semester & & & & & \\
\hline 10. & $\begin{array}{l}\text { Pengantar Tugas } 3 \\
\text { Metode Blok/Colet }\end{array}$ & $\begin{array}{l}\text { Mendengarkan } \\
\text { Melihat dan }\end{array}$ & $\begin{array}{l}\text { Tahapan dlm } \\
\text { metode blok/ }\end{array}$ & $\begin{array}{l}\text { SOP, ceramah, } \\
\text { diskusi, tanya }\end{array}$ & $\begin{array}{l}\text { Ide } \\
\text { penciptaan }\end{array}$ & $\begin{array}{l}\text { - Budi- } \\
\text { wirman }\end{array}$ \\
\hline
\end{tabular}




\begin{tabular}{|c|c|c|c|c|c|c|}
\hline & $\begin{array}{l}\text {-Pengetahuan tentang } \\
\text { Bahan dan Alat } \\
\text {-Rancangan Karya } \\
\text { - Assistensi Rancangan }\end{array}$ & $\begin{array}{l}\text { Membuat } \\
\text { Rancangan } \\
\text { Karya }\end{array}$ & $\begin{array}{l}\text { colet. } \\
\text { Pengetahuan } \\
\text { ttg bahan \& } \\
\text { alat. Meng- } \\
\text { ungkapkan } \\
\text { ide. }\end{array}$ & $\begin{array}{l}\text { jawab dan } \\
\text { resitasi }\end{array}$ & $\begin{array}{l}\text {-Tugas dan } \\
\text { rancangan } \\
\text { karya }\end{array}$ & $\begin{array}{l}\text {-Dwi } \\
\text { Marian } \\
\text { to }\end{array}$ \\
\hline 11. & $\begin{array}{l}\text { Lanjutan Tugas } 3 \\
\text {-Menggunakan bahan dan } \\
\text { alat dengan benar } \\
\text {-Pengolahan klise tahap I } \\
\text { dan proses cetak } \\
\text {-Keselamatan Kerja }\end{array}$ & $\begin{array}{l}\text { Mendengarkan } \\
\text { Melihat dan } \\
\text { Mengerjakan } \\
\text { tugas }\end{array}$ & $\begin{array}{l}\text { Karakter ttg } \\
\text { bahan \& alat. } \\
\text { Keselamatan } \\
\text { dlm penggu- } \\
\text { naan bahan \& } \\
\text { alat. Pedoman } \\
\text { pada alur } \\
\text { cetak }\end{array}$ & $\begin{array}{l}\text { SOP, ceramah, } \\
\text { diskusi, } \\
\text { demonstrasi } \\
\text { dan resitasi }\end{array}$ & $\begin{array}{l}\text { Kreativitas } \\
\text { dlm } \\
\text { menentu- } \\
\text { kan bahan } \\
\text { dan alat, } \\
\text { hasil cetak }\end{array}$ & Sda. \\
\hline 12. & $\begin{array}{l}\text { Lanjutan Tugas } 3 \\
\text {-Pengolahan klise tahap } \\
\text { II dan proses cetak } \\
\text {-Pengolahan klise tahap } \\
\text { III dan proses cetak }\end{array}$ & $\begin{array}{l}\text { Melihat dan } \\
\text { Melanjutkan } \\
\text { tugas }\end{array}$ & $\begin{array}{l}\text { Pemahaman } \\
\text { ttg pendekatan } \\
\text { Reduksio-nis. } \\
\text { (klise } \\
\text { tunggal). }\end{array}$ & $\begin{array}{l}\text { SOP, ceramah, } \\
\text { diskusi dan } \\
\text { resitasi }\end{array}$ & $\begin{array}{l}\text { Tugas } \\
\text { hasil cetak, } \\
\text { ketepatan } \\
\& \\
\text { kebersihan } \\
\text { hasil cetak }\end{array}$ & Sda. \\
\hline 13. & $\begin{array}{l}\text { Lanjutan Tugas } 3 \\
\text {-Mengatasi masalah dan } \\
\text { Keselamatan Kerja } \\
\text {-Pengolahan klise tahap } \\
\text { IV dan proses cetak } \\
\text {-Finishing }\end{array}$ & $\begin{array}{l}\text { Mendengarkan } \\
\text { Melihat dan } \\
\text { Melanjutkan } \\
\text { tugas }\end{array}$ & $\begin{array}{l}\text { Solusi/me- } \\
\text { ngatasi } \\
\text { masalah dlm } \\
\text { proses cetak } \\
\text { banyak war-na } \\
\text { (poli chrome). } \\
\text { Finishing pada } \\
\text { karya }\end{array}$ & $\begin{array}{l}\text { SOP, ceramah, } \\
\text { diskusi } \\
\text { demonstrasi } \\
\text { dan resitasi }\end{array}$ & $\begin{array}{l}\text { Tugas } \\
\text { hasil cetak, } \\
\text { ketepatan } \\
\& \\
\text { kebersihan } \\
\text { hasil cetak }\end{array}$ & Sda. \\
\hline 14. & $\begin{array}{l}\text { Pengantar Tugas } 4 \\
\text { Metode Kombinasi } \\
\text {-Pencarian Ide dan } \\
\text { Rancangan Penciptaan } \\
\text {-Assistensi Rancangan }\end{array}$ & $\begin{array}{l}\text { Mendengarkan } \\
\text { Melihat dan } \\
\text { Membuat } \\
\text { Rancangan } \\
\text { Karya }\end{array}$ & $\begin{array}{l}\text { Tahapan pen } \\
\text { carian ide \& } \\
\text { merancang } \\
\text { karya dlm } \\
\text { metode } \\
\text { kombinasi } \\
\end{array}$ & $\begin{array}{l}\text { SOP, ceramah, } \\
\text { diskusi, tanya } \\
\text { jawab dan } \\
\text { resitasi }\end{array}$ & $\begin{array}{l}\text { Ide } \\
\text { penciptaan } \\
\text {-Tugas dan } \\
\text { rancangan } \\
\text { karya }\end{array}$ & $\begin{array}{l}\text {-Buku } \\
\text { ajar, } \\
\text {-hand- } \\
\text { out }\end{array}$ \\
\hline 15. & $\begin{array}{l}\text { Lanjutan Tugas } 4 \\
\text {-Pengolahan klise tahap I } \\
\text {-Proses Cetak }\end{array}$ & $\begin{array}{l}\text { Mendengarkan } \\
\text { Melihat dan } \\
\text { Melanjutkan } \\
\text { tugas }\end{array}$ & $\begin{array}{l}\text { Tahapan dlm } \\
\text { mengolah } \\
\text { klise dan } \\
\text { melakukan } \\
\text { proses cetak }\end{array}$ & $\begin{array}{l}\text { SOP, ceramah, } \\
\text { diskusi } \\
\text { demonstrasi } \\
\text { dan resitasi }\end{array}$ & $\begin{array}{l}\text { Tugas pe- } \\
\text { ngolahan } \\
\text { klise dan } \\
\text { hasil cetak }\end{array}$ & Sda. \\
\hline 16. & $\begin{array}{l}\text { Lanjutan Tugas } 4 \\
\text {-Pengolahan klise tahap } \\
\text { II } \\
\text {-Proses Cetak } \\
\text {-Finishing } \\
\text {-Persiapan Ujian Smt. }\end{array}$ & $\begin{array}{l}\text { Mendengarkan } \\
\text { Melihat dan } \\
\text { Melanjutkan } \\
\text { tugas serta } \\
\text { mendiskusikan }\end{array}$ & $\begin{array}{l}\text { Solusi/me- } \\
\text { ngatasi } \\
\text { masalah dlm } \\
\text { proses cetak } \\
\text { banyak war-na } \\
\text { (poli chrome). }\end{array}$ & $\begin{array}{l}\text { SOP, ceramah, } \\
\text { diskusi dan } \\
\text { resitasi }\end{array}$ & $\begin{array}{l}\text { Tugas } \\
\text { hasil cetak, } \\
\text { ketepatan } \\
\& \\
\text { kebersihan } \\
\text { hasil cetak }\end{array}$ & Sda. \\
\hline
\end{tabular}


Perangkat Perkuliahan

\section{SATUAN ACARA PERKULIAHAN \\ (SAP)}

Bahan Kajian

SKS

Program Studi

Pertemuan Ke

Dosen
: Seni Grafis 2 (serigraphy)

: 3 (tiga)

: Pendidikan Seni Rupa

$: 1-2$

: Drs. Ariusmedi, M.Sn.

Drs. Irwan, M.Sn.

Learning Outcomes (Capaian Pembelajaran) terkait KKNI

Ruang Lingkup Seni Grafis serta bagian-bagiannya:

a. Sejarah singkat, perkembangan, serta potensi Serigraphy sebagai salah satu teknik dalam karya seni murni.

b. Memahami beberapa cara/metode dalam teknik Serigraphy, yang diarahkan pada aspek kreativitas kebebasan dalam berkarya seni

Soft skills/Karakter: Memahami tentang perkembangan Seni Grafis khususnya Serigraphy sebagai karya seni murni.

\section{Materi :}

a. Ruang lingkup serta perkembangan Seni Grafis dalam karya seni rupa murni.

b. Serigraphy sebagai alternatif pilihan dalam berkesenian

c. Pengetahuan tentang cetak mencetak dua dimensi

\section{Kegiatan Pembelajaran :}

\begin{tabular}{|c|l|l|l|l|}
\hline $\begin{array}{c}\text { Tahap } \\
\text { Kegiatan }\end{array}$ & \multicolumn{1}{|c|}{ Kegiatan Dosen } & \multicolumn{1}{|c|}{$\begin{array}{c}\text { Kegiatan } \\
\text { Mahasiswa }\end{array}$} & $\begin{array}{c}\text { Teknik } \\
\text { Penilaian }\end{array}$ & \multicolumn{1}{|c|}{ Media } \\
\hline Pendahuluan & Menjelaskan kontrak & Mendengarkan & $\begin{array}{l}\text { Lisan } \\
\text { Tanya } \\
\text { perkuliahan }\end{array}$ & $\begin{array}{l}\text { Silabus } \\
\text { dan Buku } \\
\text { ajar }\end{array}$ \\
& $\begin{array}{l}\text { Mengenalkan silabus } \\
\text { perkuliahan Seni } \\
\text { Grafis 2 (Serigraphy) }\end{array}$ & Menyimak sajian & Dosen & \\
& $\begin{array}{l}\text { Menjelaskan Buku } \\
\text { Sumber dan Referensi } \\
\text { pembelajaran }\end{array}$ & $\begin{array}{l}\text { Mencatat buku } \\
\text { rujukan }\end{array}$ & & \\
& & & \\
& & & \\
&
\end{tabular}




\begin{tabular}{|c|c|c|c|c|}
\hline & $\begin{array}{l}\text { - Menjelaskan target } \\
\text { kompetensi dan ruang } \\
\text { lingkup materi yang } \\
\text { akan dibahas }\end{array}$ & $\begin{array}{l}\text { Mendengar dan } \\
\text { mencatat }\end{array}$ & & \\
\hline Penyajian & $\begin{array}{l}\text { Menjelaskan Ruang } \\
\text { Lingkup Seni Grafis } \\
\text { - pengertian, sejarah, } \\
\text { karakterisik, manfaat } \\
\text { berkarya serta teknik } \\
\text { dalam Seni Grafis } \\
\text { - Menjelaskan bahan } \\
\text { dan Alat dalam } \\
\text { berkarya Serigraphy- } \\
\text { - Memberikan } \\
\text { kesempatan pada } \\
\text { mahasiswa untuk } \\
\text { mengajukan } \\
\text { pertanyaan serta } \\
\text { memperagakan } \\
\text { bahan dan alat-alat } \\
\text { yang diperlukan. }\end{array}$ & $\begin{array}{l}\text { Menyimak } \\
\text { penjelasan Dosen } \\
\text { Mendengar dan } \\
\text { mencatat } \\
\text { Mengajukan } \\
\text { pertanyaan }\end{array}$ & $\begin{array}{l}\text { Lisan } \\
\text { Tanya } \\
\text { jawab }\end{array}$ & $\begin{array}{l}\text { Buku ajar } \\
\text { Bahan dan } \\
\text { alat }\end{array}$ \\
\hline Penutup & $\begin{array}{l}\text { Memberikan } \\
\text { penguatan dan feed } \\
\text { back tentang kegiatan } \\
\text { pembelajaran }\end{array}$ & $\begin{array}{l}\text { Melakukan tindak } \\
\text { lanjut }\end{array}$ & $\begin{array}{l}\text { Lisan; } \\
\text { tanya } \\
\text { jawab }\end{array}$ & \\
\hline
\end{tabular}

Rubrik Penilaian :

Tes Pemahaman dan kreativitas belajar

\begin{tabular}{|l|l|c|c|c|c|}
\hline \multirow{2}{*}{ No } & \multicolumn{1}{|c|}{ Bentuk Soal } & \multicolumn{3}{|c|}{ Kriteria penilaian/Skor } \\
\cline { 3 - 6 } & \multicolumn{1}{|c|}{$\begin{array}{c}\text { Pema- } \\
\text { haman }\end{array}$} & $\begin{array}{c}\text { Krea- } \\
\text { tivitas }\end{array}$ & Lisan & Tulis \\
\cline { 3 - 6 } & & 30 & 20 & 30 & 20 \\
\hline 1. & $\begin{array}{l}\text { Pengetahuan tentang: } \\
\text { Ruang Lingkup Seni Grafis } \\
\begin{array}{l}\text { a. Bagian-bagian dalam Seni Grafis } \\
\text { b. Metode-metode Serigraphy } \\
\text { c. Konsep berkesenian }\end{array}\end{array}$ & & & & \\
\hline
\end{tabular}


Tes Sikap

\begin{tabular}{|c|c|c|c|c|c|c|}
\hline \multirow{2}{*}{ No } & \multirow[b]{2}{*}{$\begin{array}{l}\text { Nama } \\
\text { Mahasiswa }\end{array}$} & \multicolumn{5}{|c|}{ Sikap } \\
\hline & & Percaya diri & Ketelitian & Kerapian & Disiplin & $\begin{array}{c}\text { Tanggung } \\
\text { jawab }\end{array}$ \\
\hline & & & & & & \\
\hline & & & & & & \\
\hline & & & & & & \\
\hline & & & ata & & & \\
\hline
\end{tabular}

\section{Daftar Pustaka :}

1. Agus Sachari (1986), Desain, Gaya dan Realitas, Jakarta: Rajawali Press.

2. Antonius Bowo Wasono dkk. (2008) Teknik Grafika dan Industri Grafika, Jakarta: Penerbit Direktorat Pembinaan Sekolah Menengah Kejuruan Direktorat Jenderal Manajemen Pendidikan Dasar dan Menengah Departemen Pendidikan Nasional

3. Budiwirman (2008), Seni Grafis, (buku ajar), Padang: UNP

4. Budiwirman (2010), Seni Cetak Mencetak, Padang: Sukabina Press

5. Budiwirman (2012), Seni, Seni Grafis dan Aplikasinya dalam Pendidikan, Padang: UNP Press.

6. Diah Latifah dkk. (2000), Panduan Menguasai Pendidikan Kesenian, Bandung: Ganeca Exact.

7. Dwi Marianto M. (1988), Seni Cetak Cukil Kayu, Yogyakarta: Kanisius

8. G. Sidharta Soegijo (1997), Pameran Seni Rupa Kontemporer, ITB Bandung

9. Jim Supangkat \& Sanento Yuliman (1982), Di Tengah Seni Rupa Indonesia, Jakarta: Gramedia Publishing Division.

Lampiran-Lampiran :

1. Buku Catatan

2. Lembaran SOP (Struktur Orientasi Prosedural)

3. Buku Ajar 
Perangkat Perkuliahan

\section{SATUAN ACARA PERKULIAHAN \\ (SAP)}

Bahan Kajian

SKS

Program Studi

Pertemuan Ke

Dosen
: Seni Grafis 2 (serigraphy)

: 3 (tiga)

: Pendidikan Seni Rupa

: 3-4

: Drs. Ariusmedi, M.Sn.

Drs. Irwan, M.Sn.

Learning Outcomes (Capaian Pembelajaran) terkait KKNI

Ruang Lingkup Seni Grafis khususnya pada teknik Serigraphy

a. Prinsip kerja pada metode pola potong sebagai salah satu metode dalam teknik Serigraphy.

a. Merancang pola-pola sederhana dengan metode pola potong sebagai salah satu alternatif dalam berkarya seni

Soft skills/Karakter: Terampil mengaplikasikan potensi seni rupa dalam metode cetak sederhana menurut kaedah serta konsep berkesenian.

\section{Materi :}
a. Konsep-konsep dalam Seni Rupa
b. Prinsip kerja dan rangkaian proses dalam metode pola potong
c. Membuat rancangan sederhana dengan metode pola potong
d. Mengolah klise dan melakukan proses cetak

\section{Kegiatan Pembelajaran :}

\begin{tabular}{|c|l|l|l|l|}
\hline \multicolumn{1}{|c|}{$\begin{array}{c}\text { Tahap } \\
\text { Kegiatan }\end{array}$} & \multicolumn{1}{|c|}{ Kegiatan Dosen } & \multicolumn{1}{c|}{$\begin{array}{c}\text { Kegiatan } \\
\text { Mahasiswa }\end{array}$} & $\begin{array}{c}\text { Teknik } \\
\text { Penilaian }\end{array}$ & \multicolumn{1}{c|}{ Media } \\
\hline Pendahuluan & $\begin{array}{l}\text { - Menjelaskan target } \\
\text { kompetensi dan ruang } \\
\text { lingkup materi yang } \\
\text { akan dibahas } \\
\text { - Menjelaskan metode } \\
\text { dalam teknik } \\
\text { Serigraphy }\end{array}$ & $\begin{array}{l}\text { Mendengar dan } \\
\text { mencatat }\end{array}$ & $\begin{array}{l}\text { Lisan } \\
\text { Tanya } \\
\text { jawab }\end{array}$ & $\begin{array}{l}\text { Silabus } \\
\text { dan Buku } \\
\text { ajar }\end{array}$ \\
penjelasan Dosen & and & \\
\hline
\end{tabular}




\begin{tabular}{|c|c|c|c|c|}
\hline Penyajian & $\begin{array}{l}\text { - Tahapan dalam } \\
\text { metode pola potong } \\
\text { - Memberikan } \\
\text { kesempatan pada } \\
\text { mahasiswa untuk } \\
\text { mengajukan } \\
\text { pertanyaan serta } \\
\text { memperagakan } \\
\text { bahan dan alat-alat } \\
\text { yang diperlukan. } \\
\text { - Menugaskan kepada } \\
\text { mahasiswa untuk } \\
\text { membuat rancangan } \\
\text { karya, mengolah klise } \\
\text { dan proses cetak } \\
\text { banyak warna } \\
\text { (polychrome) }\end{array}$ & $\begin{array}{l}\text { Mendengar dan } \\
\text { mencatat } \\
\text { Mengajukan } \\
\text { pertanyaan } \\
\\
\text { Mahasiswa } \\
\text { membuat } \\
\text { rancangan karya, } \\
\text { mengolah klise, } \\
\text { melakukan proses } \\
\text { cetak dengan } \\
\text { metode pola } \\
\text { potong }\end{array}$ & $\begin{array}{l}\text { Tugas } \\
\text { latihan; } \\
\text { Ide } \\
\text { rancangan, } \\
\text { serta } \\
\text { tampilan } \\
\text { karya }\end{array}$ & $\begin{array}{l}\text { Buku ajar } \\
\text { Foto karya }\end{array}$ \\
\hline Penutup & $\begin{array}{l}\text { Memberikan } \\
\text { penguatan dan feed } \\
\text { back tentang kegiatan } \\
\text { pembelajaran }\end{array}$ & $\begin{array}{l}\text { Melakukan tindak } \\
\text { lanjut }\end{array}$ & $\begin{array}{l}\text { Lisan, } \\
\text { tanya } \\
\text { jawab }\end{array}$ & \\
\hline
\end{tabular}

\section{Rubrik Penilaian :}

Proses penciptaan karya

\begin{tabular}{|l|l|c|c|c|c|}
\hline \multirow{2}{*}{ No } & \multicolumn{1}{|c|}{ Bentuk Soal } & \multicolumn{3}{|c|}{ Kriteria penilaian/Skor } \\
\cline { 3 - 6 } & & $\begin{array}{c}\text { Rancangan } \\
\text { karya }\end{array}$ & $\begin{array}{c}\text { Kreati- } \\
\text { vitas }\end{array}$ & $\begin{array}{c}\text { Inova- } \\
\text { tif }\end{array}$ & $\begin{array}{c}\text { Finish- } \\
\text { ing }\end{array}$ \\
\cline { 3 - 6 } & & 30 & 20 & 20 & 30 \\
\hline 1. & $\begin{array}{l}\text { Karya 1: } \\
\text { - Metode Pola Potong: } \\
\text { a. Ide } \\
\text { b. Pengolahan Klise } \\
\text { c. Proses Cetak }\end{array}$ & & & & \\
\hline
\end{tabular}


Tes Sikap

\begin{tabular}{|l|l|l|l|l|l|l|}
\hline \multirow{2}{*}{ No } & \multicolumn{5}{|c|}{ Sikap } \\
$\begin{array}{l}\text { Nama } \\
\text { Mahasiswa }\end{array}$ & Percaya diri & Ketelitian & Kerapian & Disiplin & $\begin{array}{c}\text { Tanggung } \\
\text { jawab }\end{array}$ \\
\cline { 2 - 7 } & & & & & & \\
\hline & & & & & & \\
\hline & & & & & & \\
\hline & & & & & & \\
\hline & & & & & & \\
\hline & & & & & & \\
\hline & & & & & & \\
\hline
\end{tabular}

\section{Daftar Pustaka :}

1. Agus Sachari (1986), Desain, Gaya dan Realitas, Jakarta: Rajawali Press.

2. Antonius Bowo Wasono dkk. (2008) Teknik Grafika dan Industri Grafika, Jakarta: Penerbit Direktorat Pembinaan Sekolah Menengah Kejuruan Direktorat Jenderal Manajemen Pendidikan Dasar dan Menengah Departemen Pendidikan Nasional

3. Budiwirman (2008), Seni Grafis, (buku ajar), Padang: UNP

4. Budiwirman (2010), Seni Cetak Mencetak, Padang: Sukabina Press

5. Budiwirman (2012), Seni, Seni Grafis dan Aplikasinya dalam Pendidikan, Padang: UNP Press.

6. Diah Latifah dkk. (2000), Panduan Menguasai Pendidikan Kesenian, Bandung: Ganeca Exact.

7. Dwi Marianto M. (1988), Seni Cetak Cukil Kayu, Yogyakarta: Kanisius

8. G. Sidharta Soegijo (1997), Pameran Seni Rupa Kontemporer, ITB Bandung

9. Jim Supangkat \& Sanento Yuliman (1982), Di Tengah Seni Rupa Indonesia, Jakarta: Gramedia Publishing Division.

Lampiran-Lampiran :

1. Buku Catatan

2. Lembaran SOP (Struktur Orientasi Prosedural)

3. Buku Ajar 
Perangkat Perkuliahan

\section{SATUAN ACARA PERKULIAHAN \\ (SAP)}

Bahan Kajian

SKS

Program Studi

Pertemuan Ke

Dosen
: Seni Grafis 2 (serigraphy)

: 3 (tiga)

: Pendidikan Seni Rupa

: $5-8$

: Drs. Ariusmedi, M.Sn.

Drs. Irwan, M.Sn.

\section{Learning Outcomes (Capaian Pembelajaran) terkait KKNI}

Ruang Lingkup Seni Grafis khususnya pada teknik Serigraphy

a. Prinsip kerja pada metode fotografis sebagai salah satu metode dalam teknik Serigraphy.

b. Pengetahuan dalam penerapan teknologi sebagai media penciptaan karya seni yang inovatif.

b. Membuat karya seni grafis dengan memadukan unsur-unsur seni rupa yang menghasilkan karya secara utuh, diawali dengan pembuatan rancangan karya, pembuatan 'film positif', proses afdruk sampai ke proses pencetakan.

Soft skills/Karakter: Terampil mengaplikasikan potensi seni rupa serta penerapan teknologi dalam penciptaan karya seni murni.

\section{Materi :}

a. Prinsip kerja dan rangkaian proses dalam metode fotografis

b. Pengetahuan serta penerapan teknologi dalam berkarya seni murni

c. Memahami tentang konsep-konsep dan kaedah dalam berkesenian

\section{Kegiatan Pembelajaran :}

\begin{tabular}{|c|l|l|l|l|}
\hline $\begin{array}{c}\text { Tahap } \\
\text { Kegiatan }\end{array}$ & \multicolumn{1}{|c|}{ Kegiatan Dosen } & \multicolumn{1}{|c|}{$\begin{array}{c}\text { Kegiatan } \\
\text { Mahasiswa }\end{array}$} & $\begin{array}{c}\text { Teknik } \\
\text { Penilaian }\end{array}$ & Media \\
\hline Pendahuluan & $\begin{array}{l}\text { - Menjelaskan target } \\
\text { kompetensi dan ruang } \\
\text { lingkup materi yang } \\
\text { akan dibahas } \\
\text { - Menjelaskan konsep- } \\
\text { konsep dalam }\end{array}$ & $\begin{array}{l}\text { Mendengarkan } \\
\text { dan mencatat }\end{array}$ & $\begin{array}{l}\text { Lisan } \\
\text { Tanya } \\
\text { jawab }\end{array}$ & $\begin{array}{l}\text { Buku } \\
\text { ajar }\end{array}$ \\
& & & \\
\hline
\end{tabular}




\begin{tabular}{|c|c|c|c|c|}
\hline & berkesenian & & & \\
\hline Penyajian & $\begin{array}{l}\text { - Tahapan dlm metode } \\
\text { fotografis } \\
\text { - Pengetahuan tentang } \\
\text { bahan \& alat } \\
\text { - Mengungkapkan ide } \\
\text { dan etika dalam } \\
\text { berkarya } \\
\text { - Pemahaman tentang } \\
\text { film dan afdruk serta } \\
\text { mengatasi masalah } \\
\text { dalam proses afdruk } \\
\text { - Pengetahuan tentang } \\
\text { komposisi warna } \\
\text { - Mengatasi masalah } \\
\text { dalam proses cetak } \\
\text { - Memberikan } \\
\text { kesempatan pada } \\
\text { mahasiswa untuk } \\
\text { mengajukan } \\
\text { pertanyaan serta } \\
\text { memperagakan } \\
\text { penggunaan bahan } \\
\text { dan alat } \\
\text { - Menugaskan kepada } \\
\text { mahasiswa untuk } \\
\text { mengungkapkan ide } \\
\text { penciptaan serta } \\
\text { melakukan proses } \\
\text { berkarya }\end{array}$ & $\begin{array}{l}\text { Membuat } \\
\text { rancangan karya, } \\
\text { mengolah klise, } \\
\text { melakukan proses } \\
\text { cetak dengan } \\
\text { metode fotografis }\end{array}$ & $\begin{array}{l}\text { Tugas } \\
\text { latihan: } \\
\text { Ide } \\
\text { rancangan, } \\
\text { hasil } \\
\text { afdruk dan } \\
\text { karya cetak }\end{array}$ & $\begin{array}{l}\text { Foto } \\
\text { karya: G. } \\
\text { Sidharta. } \\
\text { Lingkar- } \\
\text { an warna }\end{array}$ \\
\hline Penutup & $\begin{array}{l}\text { Memberikan } \\
\text { penguatan dan feed } \\
\text { back tentang kegiatan } \\
\text { pembelajaran pada } \\
\text { pertemuan minggu ke } \\
5 \text { s.d } 8\end{array}$ & $\begin{array}{l}\text { Melakukan tindak } \\
\text { lanjut }\end{array}$ & $\begin{array}{l}\text { Lisan; } \\
\text { tanya } \\
\text { jawab }\end{array}$ & \\
\hline
\end{tabular}


Rubrik Penilaian :

Proses penciptaan karya

\begin{tabular}{|l|l|c|c|c|c|}
\hline \multirow{2}{*}{ No } & \multicolumn{1}{|c|}{ Bentuk Soal } & \multicolumn{3}{|c|}{ Kriteria penilaian/Skor } \\
\cline { 3 - 6 } & \multicolumn{1}{|c|}{$\begin{array}{c}\text { Rancangan } \\
\text { karya }\end{array}$} & $\begin{array}{c}\text { Kreati- } \\
\text { vitas }\end{array}$ & $\begin{array}{c}\text { Inova- } \\
\text { tif }\end{array}$ & $\begin{array}{c}\text { Finish- } \\
\text { ing }\end{array}$ \\
\cline { 3 - 6 } & & 30 & 20 & 20 & 30 \\
\hline 1. & $\begin{array}{l}\text { Karya 2: } \\
- \text { Metode fotografis: } \\
\text { a. Film positif } \\
\text { b. Proses Afdruk } \\
\text { c. Proses Cetak }\end{array}$ & & & & \\
\hline
\end{tabular}

Tes Sikap

\begin{tabular}{|c|l|l|l|l|l|l|}
\hline \multirow{2}{*}{ No } & \multicolumn{5}{|c|}{ Sikap } \\
\cline { 2 - 7 } & $\begin{array}{l}\text { Nama } \\
\text { Mahasiswa }\end{array}$ & Percaya diri & Ketelitian & Kerapian & Disiplin & $\begin{array}{c}\text { Tanggung } \\
\text { jawab }\end{array}$ \\
\hline & & & & & & \\
\hline & & & & & & \\
\hline & & & & & & \\
\hline
\end{tabular}

\section{Daftar Pustaka :}

1. Agus Sachari (1986), Desain, Gaya dan Realitas, Jakarta: Rajawali Press.

2. Antonius Bowo Wasono dkk. (2008) Teknik Grafika dan Industri Grafika, Jakarta: Penerbit Direktorat Pembinaan Sekolah Menengah Kejuruan Direktorat Jenderal Manajemen Pendidikan Dasar dan Menengah Departemen Pendidikan Nasional

3. Budiwirman (2008), Seni Grafis, (buku ajar), Padang: UNP

4. Budiwirman (2010), Seni Cetak Mencetak, Padang: Sukabina Press

5. Budiwirman (2012), Seni, Seni Grafis dan Aplikasinya dalam Pendidikan, Padang: UNP Press.

6. Diah Latifah dkk. (2000), Panduan Menguasai Pendidikan Kesenian, Bandung: Ganeca Exact.

7. Dwi Marianto M. (1988), Seni Cetak Cukil Kayu, Yogyakarta: Kanisius

8. G. Sidharta Soegijo (1997), Pameran Seni Rupa Kontemporer, ITB Bandung

9. Jim Supangkat \& Sanento Yuliman (1982), Di Tengah Seni Rupa Indonesia, Jakarta: Gramedia Publishing Division. 


\section{Lampiran-Lampiran :}

1. Buku Catatan

2. Lembaran SOP

3. Buku Ajar

4. Foto karya seniman terkenal 
Perangkat Perkuliahan

\section{SATUAN ACARA PERKULIAHAN \\ (SAP)}

Bahan Kajian

SKS

Program Studi

Pertemuan Ke

Dosen
: Seni Grafis 2 (serigraphy)

: 3 (tiga)

: Pendidikan Seni Rupa

: $10-13$

: Drs. Ariusmedi, M.Sn.

Drs. Irwan, M.Sn.

\section{Learning Outcomes (Capaian Pembelajaran) terkait KKNI}

a. kemampuan dalam mewujudkan ide kreatif menjadi sebuah karya seni yang bermutu, unik dan tetap menjaga 'orisinalitas' serta 'eksklusif'nya sebagai karya seni murni.

b. Membuat karya seni grafis dengan memadukan unsur-unsur seni rupa yang menghasilkan karya secara utuh, yang diawali dengan pembuatan rancangan karya, pengolahan klise secara langsung dalam metode blok/colet sampai ke proses pencetakan.

Soft skills/Karakter: Terampil mengaplikasikan potensi seni rupa serta penggunaan bahan dan alat dalam penciptaan karya seni murni.

\section{Materi :}

a. Prinsip kerja dan rangkaian proses dalam metode blok/colet

b. Pengetahuan tentang bahan dan alat serta penerapannya dalam karya seni murni

c. Memahami tentang konsep-konsep dan kaedah dalam berkesenian

\section{Kegiatan Pembelajaran :}

\begin{tabular}{|c|c|c|c|c|}
\hline $\begin{array}{c}\text { Tahap } \\
\text { Kegiatan }\end{array}$ & Kegiatan Dosen & $\begin{array}{c}\text { Kegiatan } \\
\text { Mahasiswa }\end{array}$ & $\begin{array}{c}\text { Teknik } \\
\text { Penilaian }\end{array}$ & Media \\
\hline Pendahuluan & $\begin{array}{l}\text { - Menjelaskan target } \\
\text { kompetensi dan ruang } \\
\text { lingkup materi yang } \\
\text { akan dibahas } \\
\text { - Menjelaskan tentang } \\
\text { pendekatan } \\
\text { Reduksionis. (klise } \\
\text { tunggal). }\end{array}$ & $\begin{array}{l}\text { Mendengarkan } \\
\text { dan mencatat }\end{array}$ & $\begin{array}{l}\text { Lisan } \\
\text { Tanya } \\
\text { jawab }\end{array}$ & Buku ajar \\
\hline
\end{tabular}




\begin{tabular}{|c|c|c|c|c|}
\hline Penyajian & $\begin{array}{l}\text { Menjelaskan; } \\
\text { - Tahapan dalam } \\
\text { metode blok/ colet. } \\
\text { - Tentang penggunaan } \\
\text { bahan dan alat secara } \\
\text { tepat dan benar } \\
\text { - Memberikan } \\
\text { kesempatan pada } \\
\text { mahasiswa untuk } \\
\text { mengajukan } \\
\text { pertanyaan serta } \\
\text { memperagakan } \\
\text { penggunaan bahan } \\
\text { dan alat } \\
\text { - Kiat mengolah klise } \\
\text { tahap awal sampai } \\
\text { proses cetak tahap } \\
\text { akhir } \\
\text { - Mengatasi masalah } \\
\text { dan keselamatan kerja } \\
\text { - Menjelaskan finishing } \\
\text { pada karya } \\
\text { - Assistensi Rancangan } \\
\text { - Menugaskan kepada } \\
\text { mahasiswa untuk } \\
\text { melakukan proses } \\
\text { secara komprehensif }\end{array}$ & $\begin{array}{l}\text { Mendengarkan } \\
\text { dan mencatat } \\
\text { Mendengarkan } \\
\text { dan mencatat }\end{array}$ & $\begin{array}{l}\text { Lisan } \\
\text { Tanya } \\
\text { jawab }\end{array}$ & $\begin{array}{l}\text { Karya- } \\
\text { karya } \\
\text { serigraphy }\end{array}$ \\
\hline Penutup & $\begin{array}{l}\text { - Memberikan } \\
\text { penguatan dan feed } \\
\text { back tentang kegiatan } \\
\text { pembelajaran }\end{array}$ & $\begin{array}{l}\text { Melakukan tindak } \\
\text { lanjut }\end{array}$ & $\begin{array}{l}\text { Lisan; } \\
\text { tanya } \\
\text { jawab }\end{array}$ & \\
\hline
\end{tabular}


Rubrik Penilaian :

Tes proses penciptaan karya

\begin{tabular}{|l|l|c|c|c|c|}
\hline \multirow{2}{*}{ No } & \multicolumn{1}{|c|}{ Bentuk Soal } & \multicolumn{3}{|c|}{ Kriteria penilaian/Skor } \\
\cline { 3 - 6 } & \multicolumn{1}{|c|}{$\begin{array}{c}\text { Rancangan } \\
\text { karya }\end{array}$} & $\begin{array}{c}\text { Kreati- } \\
\text { vitas }\end{array}$ & $\begin{array}{c}\text { Inova- } \\
\text { tif }\end{array}$ & $\begin{array}{c}\text { Finish- } \\
\text { ing }\end{array}$ \\
\cline { 3 - 6 } & & 30 & 20 & 20 & 30 \\
\hline 1. & $\begin{array}{l}\text { Karya 3: } \\
\text { Metode blok/colet: } \\
\text { a. Ide penciptaan } \\
\text { b. Pengolahan klise } \\
\text { c. Proses Cetak }\end{array}$ & & & & \\
\hline
\end{tabular}

Tes Sikap

\begin{tabular}{|c|c|c|c|c|c|c|}
\hline \multirow{2}{*}{ No } & \multirow[b]{2}{*}{$\begin{array}{l}\text { Nama } \\
\text { Mahasiswa }\end{array}$} & \multicolumn{5}{|c|}{ Sikap } \\
\hline & & Percaya diri & Ketelitian & Kerapian & Disiplin & $\begin{array}{c}\text { Tanggung } \\
\text { jawab }\end{array}$ \\
\hline & & & & & & \\
\hline & & & & & & \\
\hline & & & & & & \\
\hline & & & & & & \\
\hline & & & & & & \\
\hline & & & & & & \\
\hline & & & & & & \\
\hline & & & & & & \\
\hline & \multicolumn{5}{|c|}{ Rata } & \\
\hline
\end{tabular}

\section{Daftar Pustaka :}

1. Agus Sachari (1986), Desain, Gaya dan Realitas, Jakarta: Rajawali Press.

2. Antonius Bowo Wasono dkk. (2008) Teknik Grafika dan Industri Grafika, Jakarta: Penerbit Direktorat Pembinaan Sekolah Menengah Kejuruan Direktorat Jenderal Manajemen Pendidikan Dasar dan Menengah Departemen Pendidikan Nasional

3. Budiwirman (2008), Seni Grafis, (buku ajar), Padang: UNP

4. Budiwirman (2010), Seni Cetak Mencetak, Padang: Sukabina Press

5. Budiwirman (2012), Seni, Seni Grafis dan Aplikasinya dalam Pendidikan, Padang: UNP Press.

6. Diah Latifah dkk. (2000), Panduan Menguasai Pendidikan Kesenian, Bandung: Ganeca Exact. 
7. Dwi Marianto M. (1988), Seni Cetak Cukil Kayu, Yogyakarta: Kanisius

8. G. Sidharta Soegijo (1997), Pameran Seni Rupa Kontemporer, ITB Bandung

9. Jim Supangkat \& Sanento Yuliman (1982), Di Tengah Seni Rupa Indonesia, Jakarta: Gramedia Publishing Division.

Lampiran-Lampiran :
1. Buku Catatan
2. Lembaran SOP
3. Buku Ajar
4. Foto-foto karya 
Perangkat Perkuliahan

\section{SATUAN ACARA PERKULIAHAN \\ (SAP)}

Bahan Kajian

SKS

Program Studi

Pertemuan Ke

Dosen
: Seni Grafis 2 (serigraphy)

: 3 (tiga)

: Pendidikan Seni Rupa

: $14-16$

: Drs. Ariusmedi, M.Sn.

Drs. Irwan, M.Sn.

Learning Outcomes (Capaian Pembelajaran) terkait KKNI

a. Mampu menciptakan karya seni dengan memadukan berbagai metode dalam satu karya seni yang utuh, dan tetap menjaga 'orisinalitas' serta 'eksklusif' nya sebuah karya seni grafis dalam konteks seni murni.

b. Membuat karya seni grafis dengan kombinasi beberapa metode yang menghasilkan karya secara utuh, diawali dengan pembuatan rancangan karya, pengolahan klise sampai ke proses pencetakan.

Soft skills/Karakter: Terampil mengaplikasikan potensi seni rupa serta penerapan berbagai metode dalam penciptaan karya seni murni.

\section{Materi :}

a. Prinsip kerja dan rangkaian proses dalam metode kombinasi

b. Pengetahuan tentang bahan dan alat serta penerapannya dalam karya seni murni

c. Memahami tentang konsep-konsep dan kaedah dalam berkesenian

\section{Kegiatan Pembelajaran :}

\begin{tabular}{|c|c|c|c|c|}
\hline $\begin{array}{c}\text { Tahap } \\
\text { Kegiatan }\end{array}$ & Kegiatan Dosen & $\begin{array}{c}\text { Kegiatan } \\
\text { Mahasiswa }\end{array}$ & $\begin{array}{c}\text { Teknik } \\
\text { Penilaian }\end{array}$ & Media \\
\hline Pendahuluan & $\begin{array}{l}\text { - Menjelaskan target } \\
\text { kompetensi dan ruang } \\
\text { lingkup materi yang } \\
\text { akan dibahas } \\
\text { - Menjelaskan prinsip } \\
\text { serta rangkaian proses } \\
\text { dalam metode } \\
\text { kombinasi }\end{array}$ & $\begin{array}{l}\text { Mendengar dan } \\
\text { mencatat }\end{array}$ & $\begin{array}{l}\text { Lisan } \\
\text { Tanya } \\
\text { jawab }\end{array}$ & Buku ajar \\
\hline
\end{tabular}




\begin{tabular}{|c|c|c|c|c|}
\hline Penyajian & $\begin{array}{l}\text { Menjelaskan: } \\
\text { - Tentang } \\
\text { mengungkapkan ide } \\
\text { penciptaan dalam } \\
\text { metode kombinasi } \\
\text { - Memberikan } \\
\text { kesempatan pada } \\
\text { mahasiswa untuk } \\
\text { mengajukan } \\
\text { pertanyaan } \\
\text { - Konsep dalam } \\
\text { berkarya seni } \\
\text { - Mengatasi masalah } \\
\text { dan keselamatan kerja } \\
\text { - Menjelaskan finishing } \\
\text { pada karya } \\
\text { - Assistensi Rancangan } \\
\text { - Menugaskan kepada } \\
\text { mahasiswa untuk } \\
\text { melakukan proses } \\
\text { secara komprehensif }\end{array}$ & $\begin{array}{l}\text { Membuat } \\
\text { rancangan karya, } \\
\text { mengolah klise } \\
\text { dengan metode } \\
\text { kombinasi, } \\
\text { melakukan } \\
\text { proses cetak } \\
\text { multi colour }\end{array}$ & $\begin{array}{l}\text { Tugas: ide } \\
\text { penciptaan } \\
\text { dan } \\
\text { produk }\end{array}$ & Buku ajar \\
\hline Penutup & $\begin{array}{l}\text { Memberikan penguatan } \\
\text { dan feed back tentang } \\
\text { kegiatan pembelajaran }\end{array}$ & $\begin{array}{l}\text { Melakukan } \\
\text { tindak lanjut }\end{array}$ & $\begin{array}{l}\text { Lisan; } \\
\text { tanya } \\
\text { jawab }\end{array}$ & \\
\hline
\end{tabular}

\section{Rubrik Penilaian :}

Tes proses penciptaan karya

\begin{tabular}{|l|l|c|c|c|c|}
\hline No & \multicolumn{1}{|c|}{ Bentuk Soal } & \multicolumn{3}{c|}{ Kriteria penilaian/Skor } \\
\cline { 3 - 6 } & & $\begin{array}{c}\text { Rancangan } \\
\text { karya }\end{array}$ & $\begin{array}{c}\text { Kreati- } \\
\text { vitas }\end{array}$ & $\begin{array}{c}\text { Inova- } \\
\text { tif }\end{array}$ & $\begin{array}{c}\text { Finish- } \\
\text { ing }\end{array}$ \\
\cline { 3 - 6 } & & 30 & 20 & 20 & 30 \\
\hline 1. & $\begin{array}{l}\text { Karya 4: } \\
\text { - Metode Kombinasi: } \\
\text { a. Ide penciptaan } \\
\text { b. Pengolahan klise } \\
\text { c. Proses Cetak }\end{array}$ & & & & \\
\hline
\end{tabular}


Tes Sikap

\begin{tabular}{|l|l|l|l|l|l|l|}
\hline \multirow{2}{*}{ No } & \multicolumn{5}{|c|}{ Sikap } \\
\cline { 2 - 6 } & $\begin{array}{l}\text { Nama } \\
\text { Mahasiswa }\end{array}$ & Percaya diri & Ketelitian & Kerapian & Disiplin & $\begin{array}{c}\text { Tanggung } \\
\text { jawab }\end{array}$ \\
\hline & & & & & & \\
\hline & & & & & & \\
\hline & & & & & & \\
\hline
\end{tabular}

Daftar Pustaka :

1. Agus Sachari (1986), Desain, Gaya dan Realitas, Jakarta: Rajawali Press.

2. Antonius Bowo Wasono dkk. (2008) Teknik Grafika dan Industri Grafika, Jakarta: Penerbit Direktorat Pembinaan Sekolah Menengah Kejuruan Direktorat Jenderal Manajemen Pendidikan Dasar dan Menengah Departemen Pendidikan Nasional

3. Budiwirman (2008), Seni Grafis, (buku ajar), Padang: UNP

4. Budiwirman (2010), Seni Cetak Mencetak, Padang: Sukabina Press

5. Budiwirman (2012), Seni, Seni Grafis dan Aplikasinya dalam Pendidikan, Padang: UNP Press.

6. Diah Latifah dkk. (2000), Panduan Menguasai Pendidikan Kesenian, Bandung: Ganeca Exact.

7. Dwi Marianto M. (1988), Seni Cetak Cukil Kayu, Yogyakarta: Kanisius

8. G. Sidharta Soegijo (1997), Pameran Seni Rupa Kontemporer, ITB Bandung

9. Jim Supangkat \& Sanento Yuliman (1982), Di Tengah Seni Rupa Indonesia, Jakarta: Gramedia Publishing Division.

Lampiran-Lampiran :

1. Buku Catatan

2. Lembaran SOP

3. Buku Ajar

4. Foto-foto karya 